\title{
Atomic Layer Deposition for Preparation of Highly Efficient Catalysts for Dry Reforming of Methane
}

\author{
Soong Yeon Kim ${ }^{1,+}$, Byeong Jun Cha ${ }^{1,+}$, Shahid Saqlain ${ }^{1}$, Hyun Ook Seo ${ }^{2, *}$ and \\ Young Dok Kim ${ }^{1} *$ (D) \\ 1 Department of Chemistry, Sungkyunkwan University, Suwon 16419, Korea; sykim086@naver.com (S.Y.K.); \\ ckqudwns223@gmail.com (B.J.C.); shahidSaqlain@hotmail.com (S.S.) \\ 2 Department of Chemistry and Energy Engineering, Sangmyung University, Seoul 03016, Korea \\ * Correspondence: hyun.ook.seo@smu.ac.kr (H.O.S.); ydkim91@skku.edu (Y.D.K.); \\ Tel.: +82-010-3555-3164 (H.O.S.); +82-010-9163-8045 (Y.D.K.) \\ + These authors contributed equally to this work.
}

Received: 28 January 2019; Accepted: 13 March 2019; Published: 15 March 2019

check for updates

\begin{abstract}
In this article, the structural and chemical properties of heterogeneous catalysts prepared by atomic layer deposition (ALD) are discussed. Oxide shells can be deposited on metal particles, forming shell/core type catalysts, while metal nanoparticles are incorporated into the deep inner parts of mesoporous supporting materials using ALD. Both structures were used as catalysts for the dry reforming of methane (DRM) reaction, which converts $\mathrm{CO}_{2}$ and $\mathrm{CH}_{4}$ into $\mathrm{CO}$ and $\mathrm{H}_{2}$. These ALD-prepared catalysts are not only highly initially active for the DRM reaction but are also stable for long-term operation. The origins of the high catalytic activity and stability of the ALD-prepared catalysts are thoroughly discussed.
\end{abstract}

Keywords: atomic layer deposition; dry reforming of methane; nickel; shell-core type nanoparticle; mesoporous media; surface basicity

\section{Introduction}

Carbon dioxide is the most important greenhouse gas responsible for climate change; therefore, suppression of its concentration in the atmosphere has been of particular importance over the last several decades [1-4]. Thus, how to efficiently capture and store $\mathrm{CO}_{2}$ from the emissions of vehicles and power plants has been extensively studied. A variety of storage media such as porous materials including a metal-organic framework (MOF) or compounds with high $\mathrm{CO}_{2}$ affinity such as $\mathrm{CaO}$ or $\mathrm{MgO}$ have been studied [4-12]. More recently, chemical conversion of $\mathrm{CO}_{2}$ has been drawing more attention, since this process is not only able to contribute to the reduction of $\mathrm{CO}_{2}$ levels in the atmosphere but also produces value-added products from $\mathrm{CO}_{2}$ [2,13-31].

There are diverse ways of converting $\mathrm{CO}_{2}$ into more valuable chemical compounds. $\mathrm{CO}_{2}$ can be electrochemically or photo-chemically reduced to many valuable chemicals such as $\mathrm{CO}, \mathrm{CH}_{3} \mathrm{OH}$, and $\mathrm{HCOOH}$ [14-17]. In these processes, it is often important to use a proper heterogeneous catalyst to increase the selectivity of a specific reaction product as well as the total reaction yield. Using chemical reactions between $\mathrm{CO}_{2}$ and other compounds, valuable materials such as polycarbonate plastics can be produced [18-20]. There are also thermal catalytic reactions such as hydrogenation of $\mathrm{CO}_{2}$, in which $\mathrm{CO}_{2}$ reacts with $\mathrm{H}_{2}$ to form $\mathrm{CO}$ and $\mathrm{H}_{2} \mathrm{O}$ [21-23]. The abovementioned reactions using $\mathrm{CO}_{2}$ as a reactant are generally endothermic due to the high thermodynamic stability of $\mathrm{CO}_{2}$. Therefore, energy needs to be provided in various forms (electric, thermal, or photon energy) to carry out these reactions even in the presence of highly active catalysts. Therefore, these reactions should be coupled with 
alternative energy sources such as solar or wind energy [2,24-26]. The $\mathrm{CO}_{2}$ chemical conversion can be considered as a possibility to store sustainable energy.

Dry reforming of methane (DRM) uses $\mathrm{CO}_{2}$ and $\mathrm{CH}_{4}$ as reactants to produce $\mathrm{CO}$ and $\mathrm{H}_{2}$. This reaction is highly endothermic, typically operating at $800{ }^{\circ} \mathrm{C}$ or higher [27-29]. Once this reaction can operate with long-term stability, the efficient production of syngas $\left(\mathrm{CO}\right.$ and $\left.\mathrm{H}_{2}\right)$ from two major greenhouse gases $\left(\mathrm{CO}_{2}\right.$ and $\left.\mathrm{CH}_{4}\right)$ can be realized. However, even if alternative energy sources are available to maintain the reactor temperature sufficiently high enough for the catalytic DRM reaction, the catalysts used for this reaction generally do not endure such high temperatures for a long time as they rapidly undergo catalytic deactivation with time, which is the major hurdle of the DRM reaction $[13,28,30]$.

$\mathrm{Ni}$ has been considered as a DRM catalyst in the past, yet bare Ni catalyst was shown to be inappropriate for this reaction since its catalytic activity drastically decreases with time due to the formation of a graphitic carbon layer on the Ni surface, which blocks catalytically active Ni sites [13,30,32]. Either disproportionation of $\mathrm{CH}_{4}$ into $\mathrm{C}_{(\mathrm{s})}$ and $\mathrm{H}_{2}$ or $\mathrm{CO}$ into $\mathrm{C}$ and $\mathrm{O}_{2}\left(\right.$ or $\mathrm{H}_{2} \mathrm{O}$ by reaction with $\mathrm{H}_{2}$ ) can result in deposition of a graphitic carbon layer (coke) on the surface of $\mathrm{Ni}[30,33-36]$.

There are several different strategies for preparing coke-resistant DRM catalysts. For example, diverse composite materials consisting of catalytically active $\mathrm{Ni}$ and other metal oxides can be used, resulting in reduced coke formation due to, for example, the high adsorption energy of $\mathrm{CO}_{2}$ on metal oxide surfaces $[13,31,37-40]$. Please note that $\mathrm{CO}_{2}$ can react with coke to form $\mathrm{CO}$, releasing the deposited coke from the catalyst surface. Nanoparticles of $\mathrm{Ni}$ were deposited on supporting materials, and the supported catalyst was used for the DRM reaction. Here, nanoparticles were shown to be more resistant toward coke formation than larger $\mathrm{Ni}$ terraces, since small $\mathrm{Ni}$ nanoparticles with a high curvature can suppress the formation of two-dimensional graphite domains [41-43]. Nevertheless, the low thermal stability of nanoparticles against agglomeration is a problem that needs to be solved [44-46].

Atomic layer deposition (ALD) has been widely used in the thin film deposition process of electronic and optical device fabrication [47-53]. Over the past few decades, application of ALD in the synthesis of heterogeneous catalysts has been vigorously considered [13,30,54-59]. In this article, the operation principles and advantages of ALD are briefly summarized. In addition, the structure, chemical uniqueness, and catalytic behavior toward the DRM reaction of ALD-prepared heterogeneous catalysts are reviewed together with potential applications. Two different types of structures prepared by employing ALD as heterogeneous catalysts for the DRM reaction are discussed: (1) shell/core-type, metal-oxide/metal catalyst prepared by depositing additional metal-oxide thin films $\left(\mathrm{MgO}, \mathrm{TiO}_{2}\right.$, $\mathrm{ZnO}$ ) onto Ni particles using ALD and (2) Ni nanoparticles confined in the mesoporous supporting templates prepared via ALD deposition of $\mathrm{NiO}$ on mesoporous materials (silica, alumina) followed by thermal annealing in a reducing atmosphere.

\section{Shell-Core-Type DRM Catalysts Prepared by ALD}

Figure 1a shows a schematic of the ALD process [47,60-63]. In principle, one can use more than two precursors to deposit thin films of diverse chemical compositions. In Figure 1a, a simple situation for depositing metal oxide thin films using an inorganic metal precursor and an oxidizing agent such as $\mathrm{H}_{2} \mathrm{O}$ is described. In the first step, a sufficiently large amount of the metal precursor vapor consisting of metal atoms and organic ligands (e.g., $\mathrm{Ti}\left[\mathrm{OCH}\left(\mathrm{CH}_{3}\right)_{2}\right]_{4}, \mathrm{Mg}(\mathrm{Cp})_{2}$, or $\left.\mathrm{Ni}(\mathrm{Cp})_{2}\right)$ is supplied into the vacuum chamber where substrates are located. Then, only precursors chemisorbed on the substrate surface remain, whereas physiosorbed species and precursor vapors in the gas phase are removed by purging with inert gases and pumping. Subsequently, oxidizing agent vapor such as $\mathrm{H}_{2} \mathrm{O}(\mathrm{g})$ or $\mathrm{O}_{2}(\mathrm{~g})$ is introduced into the chamber and reacts with chemisorbed metal precursors to form the metal oxide and $\mathrm{CO}_{2}(\mathrm{~g})$ and $\mathrm{H}_{2} \mathrm{O}(\mathrm{g})$ upon oxidation of the organic ligands. The aforementioned steps constitute one cycle of ALD, and 2-6 cycles of ALD generally form a metal-oxide monolayer, depending on the molecular structures of the inorganic precursors [63-68]. 

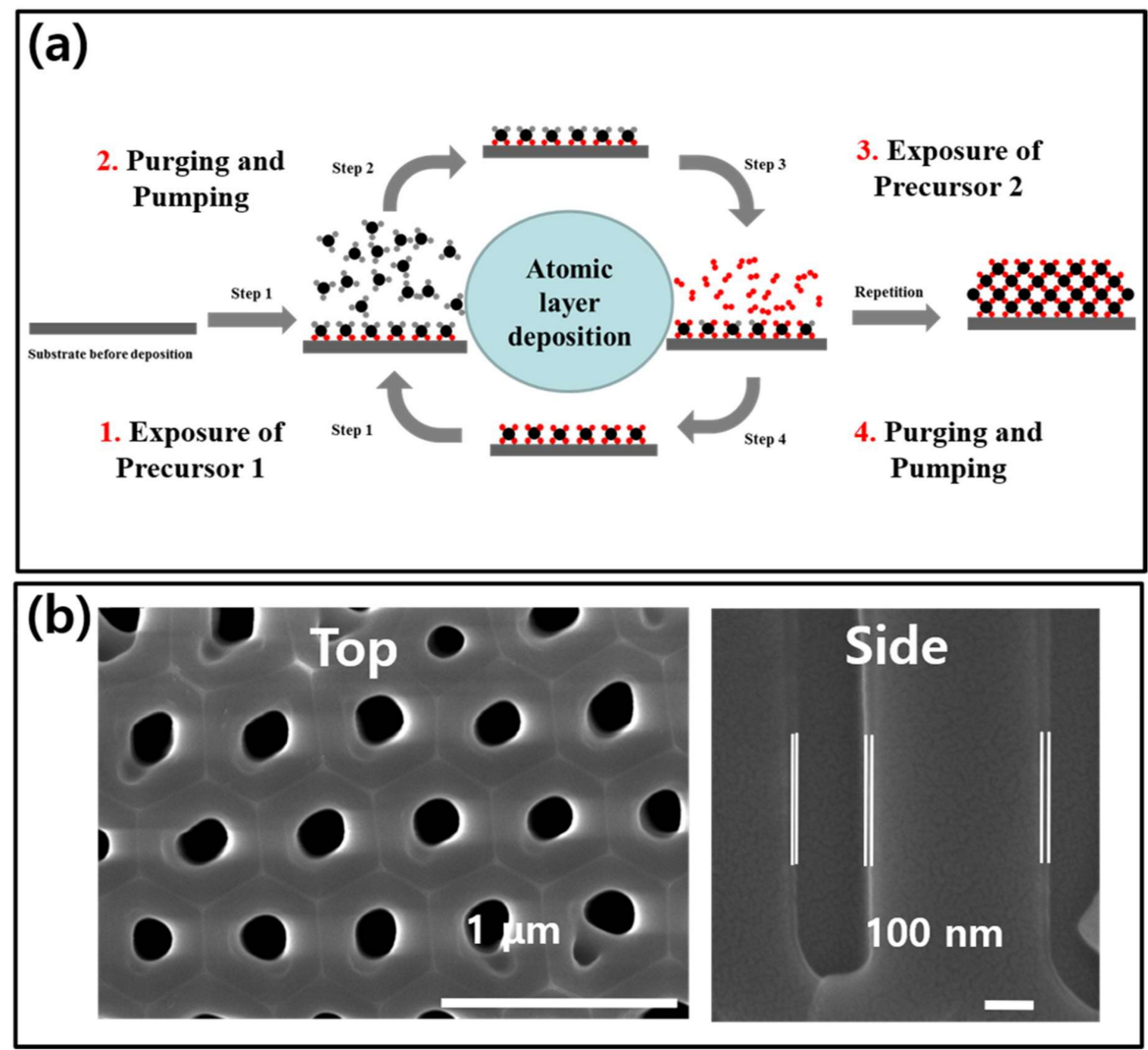

Figure 1. (a) The operating principle of atomic layer deposition is schematically described. (b) Scanning Electron Microscopy (SEM) images of $\mathrm{TiO}_{2}$ thin films on anodic aluminum oxide substrates deposited using atomic layer deposition (ALD). Edited from Reference [69].

A clear advantage of ALD with respect to chemical vapor deposition (CVD), in which two different precursors are provided at the same time onto the substrate surface, is that the thickness of thin films can be controlled on the atomic scale. ALD has been widely employed for fabrication of diverse functional thin films of electronic and optical devices owing to its ability to finely control film thickness [70-82]. Another advantage of ALD is the formation of conformal thin films on complex structured surfaces. As an example, $\mathrm{TiO}_{2}$ thin films with thicknesses less than $10 \mathrm{~nm}$ were deposited on an anodic aluminum oxide (AAO) membrane consisting of regularly ordered 200-nm-sized pores using ALD and the resulting structure consisted of a homogeneous coating of $\mathrm{TiO}_{2}$ without deteriorating the original porous substrate structure of AAO (Figure 1b,c) [69]. The ALD-prepared nanostructure $\mathrm{TiO}_{2}$ with a regularly ordered pore structure demonstrated a superior toluene adsorption efficiency of 3.8 toluene molecules $/ \mathrm{nm}^{2}$ by applying 300 ALD cycles [69].

Conventionally, catalytic active metals supported by metal oxides are considered heterogeneous catalysts. Both the geometrical structure (size, shape, morphology) and electronic nature (oxidation states) of the supported metal are related to its catalytic activity. The catalytic activity of conventional metal/metal oxide catalysts can also be influenced by underlying metal oxide supports. The geometrical and electronic structures of the supported metals can be influenced by underlying metal oxides. In addition, the catalytic behaviors of metal/metal oxide catalysts can be varied 
depending on the choice of metal oxide materials as supports by providing dissimilar metal/metal oxide interface sites as well as the participation of metal oxides in the catalytic reaction. Alternatively, the metal oxide can be deposited on metal particles (metal oxide/metal) which is often referred to as an inverse catalyst [83-86]. These metal oxide/metal systems have been studied to elucidate the contribution of the metal oxide interface on catalytic activity since the 1940s [83-86]. A large number of research groups have investigated inverse catalysts, and it has been reported that some inverse catalysts exhibit even higher activities than regularly structured catalysts (metal/metal oxides) consisting of the same compounds $[84,87]$.

Owing to the excellent trench filling capability and controllability of the metal oxide film thickness of ALD, as mentioned above, the ALD technique can be very useful in studies of inverse catalysts by fabricating various thin metal oxide films with different thicknesses on metal particles. The experimental results showing the utilization of ALD in the fabrication of various metal oxide thin films $\left(\mathrm{MgO}, \mathrm{TiO}_{2}, \mathrm{ZnO}\right)$ on Ni particles are summarized below including their catalytic behaviors towards the DRM reaction.

Ni particles (Sigma Aldrich) with diameters of $0.5-1 \mu \mathrm{m}$ were loaded into a home-made sample container, in which particles are maintained and where precursor vapors can penetrate into the container and be purged during the ALD process. ALD was used to deposit metal oxide thin films on $\mathrm{Ni}$ particles and, as shown in Figure 2, either $\mathrm{TiO}_{2}$ or $\mathrm{MgO}$ thin layers homogeneously wrapping the Ni particles could be prepared $[13,30]$. Ti $\left[\mathrm{OCH}\left(\mathrm{CH}_{3}\right)_{2}\right]_{4}$ bought from Sigma Aldrich (St. Louis, MO, USA) was used as the Ti precursor for deposition of $\mathrm{TiO}_{2}$ films, while $\mathrm{Mg}(\mathrm{Cp})_{2}$ purchased from EG Chem Co. Ltd (Daegu, Korea) was used as the $\mathrm{Mg}$ precursor for deposition of $\mathrm{MgO}$ films. For both cases ( $\mathrm{TiO}_{2}$ and $\mathrm{MgO}$ deposition), $\mathrm{H}_{2} \mathrm{O}$ vapor was used as the oxidizing agent. By altering the number of ALD cycles, the thickness of the metal oxide thin layers could be finely altered [88].
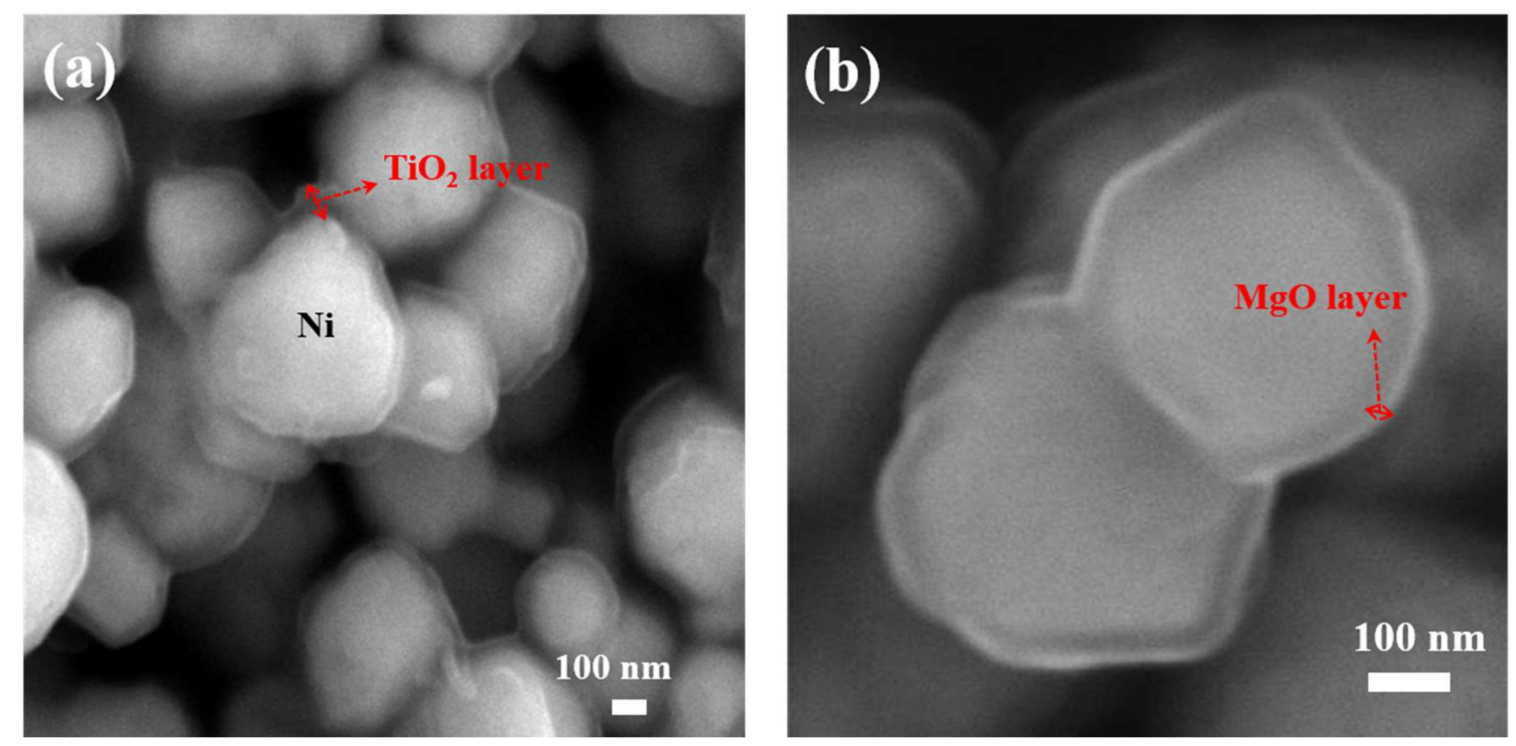

Figure 2. Transmission electron microscopy (TEM) images of (a) $\mathrm{TiO}_{2} / \mathrm{Ni}$ particles and (b) $\mathrm{MgO} / \mathrm{Ni}$ particles prepared by applying 500 and 200 cycles of ALD, respectively. Edited from Reference [13,30].

The ALD process generally operates below $300{ }^{\circ} \mathrm{C}$, where metal oxide layers tend to show amorphous structures with rather ill-defined oxidation numbers of metal atoms as opposed to highly crystalline structures [69]. During ALD under relatively low-temperature conditions, organic ligands and metal atoms are not completely oxidized, resulting in the formation of thin films with ill-defined structural properties. Only upon a proper post-annealing process of the ALD-prepared structure can stoichiometric metal oxide layers be formed, for example, annealing for $5 \mathrm{~h}$ at $800{ }^{\circ} \mathrm{C}$ under an $\mathrm{N}_{2}$ atmosphere led to the formation of stoichiometric $\mathrm{TiO}_{2}$ layers $[13,30]$. The specific areas and pore volumes of the samples (bare $\mathrm{Ni}, \mathrm{MgO} / \mathrm{Ni}, \mathrm{TiO}_{2} / \mathrm{Ni}$ ) were determined by Brunauer-Emmett-Teller 
(BET) and Barret-Joyner-Halenda (BJH) methods, respectively, and they are summarized in Table 1. An interesting aspect of the post-annealed metal-oxide/Ni structure compared to a bare Ni substrate is that the specific surface area or pore volume can increase with increasing thickness of metal oxide films prepared by ALD. For example, the surface area of $\mathrm{TiO}_{2} / \mathrm{Ni}$ prepared by 500 ALD cycles was 25 $\mathrm{m}^{2} / \mathrm{g}$ and this value is much larger than that of bare $\mathrm{Ni}\left(3.5 \mathrm{~m}^{2} / \mathrm{g}\right)$ [30]. On the other hand, $\mathrm{MgO} / \mathrm{Ni}$ prepared by 200 ALD cycles had a specific surface area of $1.9 \mathrm{~m}^{2} / \mathrm{g}$ which is lower than the respective value of bare $\mathrm{Ni}$. It is likely that a $\mathrm{MgO}$ thin film with a smooth surface structure deposited on a rough $\mathrm{Ni}$ surface decreases the specific surface area. However, the pore volume increases from 0.005 to 0.008 $\mathrm{cm}^{3} / \mathrm{g}$ by depositing $\mathrm{MgO}$ on Ni particles [13]. These results can only be understood in terms of crack formation in the oxide layers prepared by ALD and post-annealing. The formation of cracks during fabrication of $\mathrm{TiO}_{2}$ or $\mathrm{MgO}$ crystalline layers on $\mathrm{Ni}$ can result from the non-flat substrate surface structure of Ni particles since the curvature of the crystalline layer can induce strain on the thin film layer and result in crack formation.

Table 1. Brunauer-Emmett-Teller (BET) surface area and Barret-Joyner-Halenda (BJH) pore volume of bare $\mathrm{Ni}, \mathrm{MgO} / \mathrm{Ni}$ (50 and 200 ALD cycles), and $\mathrm{TiO}_{2} / \mathrm{Ni}$ (100 and 500 ALD cycles). The ALD-deposited metal oxide thicknesses of $\mathrm{MgO} / \mathrm{Ni}$ (200 cycles) and $\mathrm{TiO}_{2} / \mathrm{Ni}$ (500 cycles) determined by TEM analysis are also summarized.

\begin{tabular}{|c|c|c|c|c|c|}
\hline Catalyst & $\begin{array}{c}\text { Number of } \\
\text { Cycles }\end{array}$ & $\begin{array}{l}\text { BET Surface } \\
\text { Area }\left(\mathrm{m}^{2} / \mathrm{g}\right)\end{array}$ & $\begin{array}{c}\text { BJH Pore Volume } \\
\left(\mathrm{cm}^{3} / \mathrm{g}\right)\end{array}$ & $\begin{array}{l}\text { Mean Thickness } \\
\text { of Metal Oxide }\end{array}$ & Reference \\
\hline Bare Ni & - & 3.5 & $5.5 \times 10^{-3}$ & - & {$[13,30]$} \\
\hline \multirow{2}{*}{$\mathrm{MgO} / \mathrm{Ni}$} & 50 & 3.5 & $4.3 \times 10^{-3}$ & - & \multirow{2}{*}{ [13] } \\
\hline & 200 & 1.9 & $7.5 \times 10^{-3}$ & $\sim 20$ & \\
\hline \multirow{2}{*}{$\mathrm{TiO}_{2} / \mathrm{Ni}$} & 100 & 4.9 & $5 \times 10^{-3}$ & - & \multirow{2}{*}{ [30] } \\
\hline & 500 & 25 & $1.3 \times 10^{-3}$ & $\sim 40$ & \\
\hline
\end{tabular}

The metal-oxide-wrapped Ni particles were used as catalysts for the DRM reaction at $800{ }^{\circ} \mathrm{C}$ and the catalytic activity patterns of bare and oxide-wrapped Ni particles are presented in Figure $3[13,30]$. The DRM reaction was carried out using a vertical fixed-bed quartz reactor under atmospheric pressure. Quart wool loaded with $0.1 \mathrm{~g}$ of catalysts was placed in the center of the quartz reactor. The gas mixture of $\mathrm{CH}_{4}$ and $\mathrm{CO}_{2}$ at a ratio of 1:1 was continuously fed into the reactor at a constant total flow rate $(20 \mathrm{~mL} / \mathrm{min})[13,30]$. Generally, bare $\mathrm{Ni}$ as a catalyst shows high initial activity for conversion of $\mathrm{CO}_{2}$ and $\mathrm{CH}_{4}$ and high initial yields of $\mathrm{H}_{2}$ and $\mathrm{CO}$, which are syngas products. The production of $\mathrm{CO}$ is generally slightly higher than that of $\mathrm{H}_{2}$ since $\mathrm{H}_{2}$ produced in the DRM can further react with $\mathrm{CO}_{2}$ to form $\mathrm{CO}$ and $\mathrm{H}_{2} \mathrm{O}$ which is the reverse process of the water-gas shift reaction [89]. This process also contributes to the phenomenon in which $\mathrm{CO}_{2}$ conversion is generally higher than that of $\mathrm{CH}_{4}$ during the DRM reaction. As a function of reaction time, however, the conversion rates of the reactants and the formation rates of the products, as well as the $\mathrm{H}_{2} / \mathrm{CO}$ ratio, drastically decrease. Such a deactivation process of the DRM reaction using $\mathrm{Ni}$ as a catalyst is a well-known phenomenon and is attributed to coke formation on the Ni surfaces, poisoning catalytically active bare Ni sites [30,90-92].

For Ni particles wrapped by $\mathrm{MgO}$ using ALD, improvement in both initial catalytic activity and sustainability of the catalytic activity with respect to bare $\mathrm{Ni}$ are observed. On the other hand, the initial catalytic activities of $\mathrm{TiO}_{2} / \mathrm{Ni}$ catalysts were slightly higher or lower than those of bare $\mathrm{Ni}$ depending on the number of ALD cycles applied for $\mathrm{TiO}_{2}$ deposition (100 cycles or 500 cycles). However, ALD deposition of $\mathrm{TiO}_{2}$ thin layers (either 100 or 500 cycles) always resulted in improved catalytic sustainability of $\mathrm{Ni}$ particles. These results indicate that $\mathrm{TiO}_{2}$ or $\mathrm{MgO}$ deposited on $\mathrm{Ni}$ does not completely block the active Ni sites, which can be attributed to the aforementioned crack formation within $\mathrm{TiO}_{2}$ or $\mathrm{MgO}$ layers wrapping $\mathrm{Ni}$ particles. $\mathrm{CH}_{4}$ and $\mathrm{CO}_{2}$ molecules can diffuse via the cracks of $\mathrm{TiO}_{2}$ and $\mathrm{MgO}$ and react to form $\mathrm{CO}$ and $\mathrm{H}_{2}$ on catalytically active Ni sites. In addition, 
with increasing thickness of $\mathrm{TiO}_{2}$ or $\mathrm{MgO}$ layers within $20 \mathrm{~nm}$ of the film thickness, the initial reactivity and stability of catalyst are enhanced $[13,30]$. Even though the $\mathrm{TiO}_{2}$ shell shows higher surface areas corresponding to the higher crack density than $\mathrm{MgO}, \mathrm{MgO}$ produces much higher enhancement effects of the catalytic activity and stability of $\mathrm{Ni}$ for $\mathrm{DRM}$ than $\mathrm{TiO}_{2}$ shells. The origin of this result will be discussed in detail later. Ultimately, $\mathrm{MgO} / \mathrm{Ni}$ with an $\mathrm{MgO}$ shell thickness of $\sim 20 \mathrm{~nm}$ did not show any deactivation for DRM under ambient pressure conditions for longer than 3 days (Figure $3 \mathrm{a}-\mathrm{c}$ ).

(a)

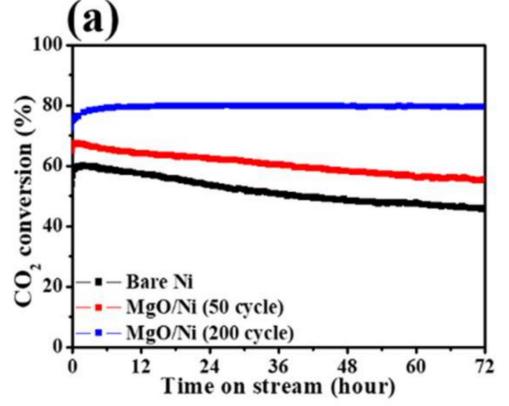

(d)

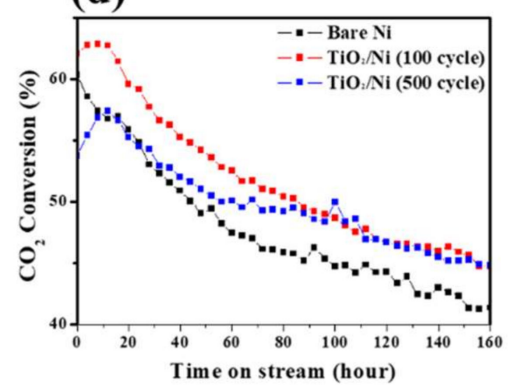

(b)

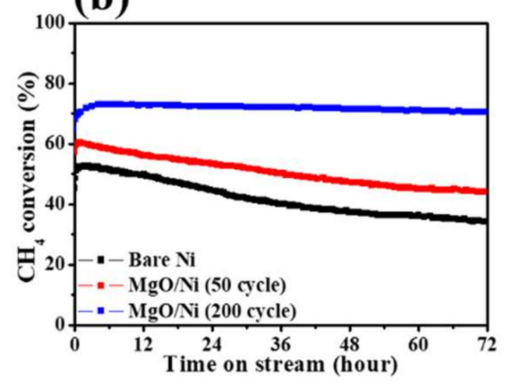

(e)

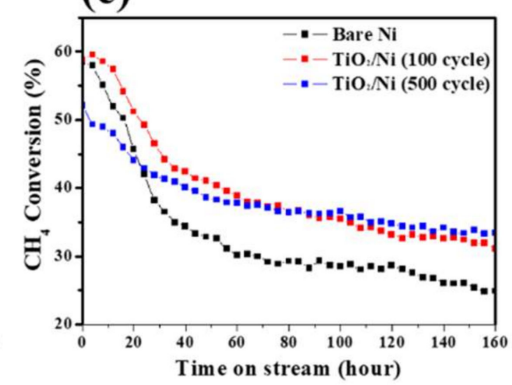

(c)
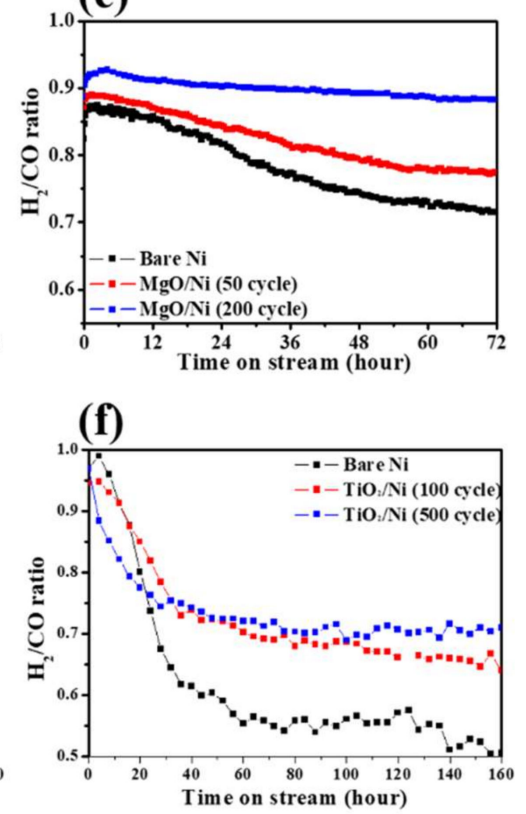

Figure 3. (a) $\mathrm{CO}_{2}$ conversion, (b) $\mathrm{CH}_{4}$ conversion, and (c) $\mathrm{H}_{2} / \mathrm{CO}$ ratio, which are products of the DRM reaction, are compared for bare $\mathrm{Ni}$ and $\mathrm{MgO}$-wrapped $\mathrm{Ni}$ with two different $\mathrm{MgO}$ thicknesses. (d-f) show the respective data for bare and $\mathrm{TiO}_{2}$-wrapped Ni. The dry reforming of methane (DRM) reactions were carried out at $800{ }^{\circ} \mathrm{C}$ under atmospheric conditions with a constant flow of the gas mixture $\left(\mathrm{CH}_{4}: \mathrm{CO}_{2}=1: 1\right.$, total flow rate of $\left.20 \mathrm{~mL} / \mathrm{min}\right)$. The number of ALD cycles used for preparing each metal oxide-wrapped $\mathrm{Ni}$ is denoted in the respective figure legend. Edited from Reference $[13,30]$.

To shed light on the origin of the enhanced catalytic activity upon $\mathrm{TiO}_{2}$ or $\mathrm{MgO}$ deposition on $\mathrm{Ni}$ particles, detailed characterization of the catalysts using X-ray diffraction (XRD) and scanning electron microscopy (SEM) was carried out (Figure $4 a-d$ ) after the catalysts were used for DRM reactions $[13,30]$. A generally observed phenomenon from $\mathrm{TiO}_{2}$ - or $\mathrm{MgO}$-wrapped Ni particles is the formation of carbon filaments on the surface of catalysts after the DRM reaction. In contrast, on bare Ni particle surfaces, two-dimensional graphitic carbon layers are formed. These results are schematically summarized in Figure 4e. There is another effect of the $\mathrm{MgO}$ film, which is Lewis-basic and therefore shows high affinity to $\mathrm{CO}_{2}$, which was verified by $\mathrm{CO}_{2}$ temperature programmed desorption [13,93-95]. With increasing $\mathrm{MgO}$ thickness, the number of moderate $\mathrm{MgO}$ adsorption sites decreased, whereas that of stronger adsorption sites of $\mathrm{CO}_{2}$, which can be attributed to under-coordinated surface $\mathrm{O}$ species of $\mathrm{MgO}$, increased. When the $\mathrm{CO}_{2}$ affinity of the catalyst surface increases, the reverse Boudouard reaction $\left(\mathrm{C}+\mathrm{CO}_{2} \rightarrow 2 \mathrm{CO}\right)$ can become faster, which can contribute to the removal of coke from the catalyst surface. 

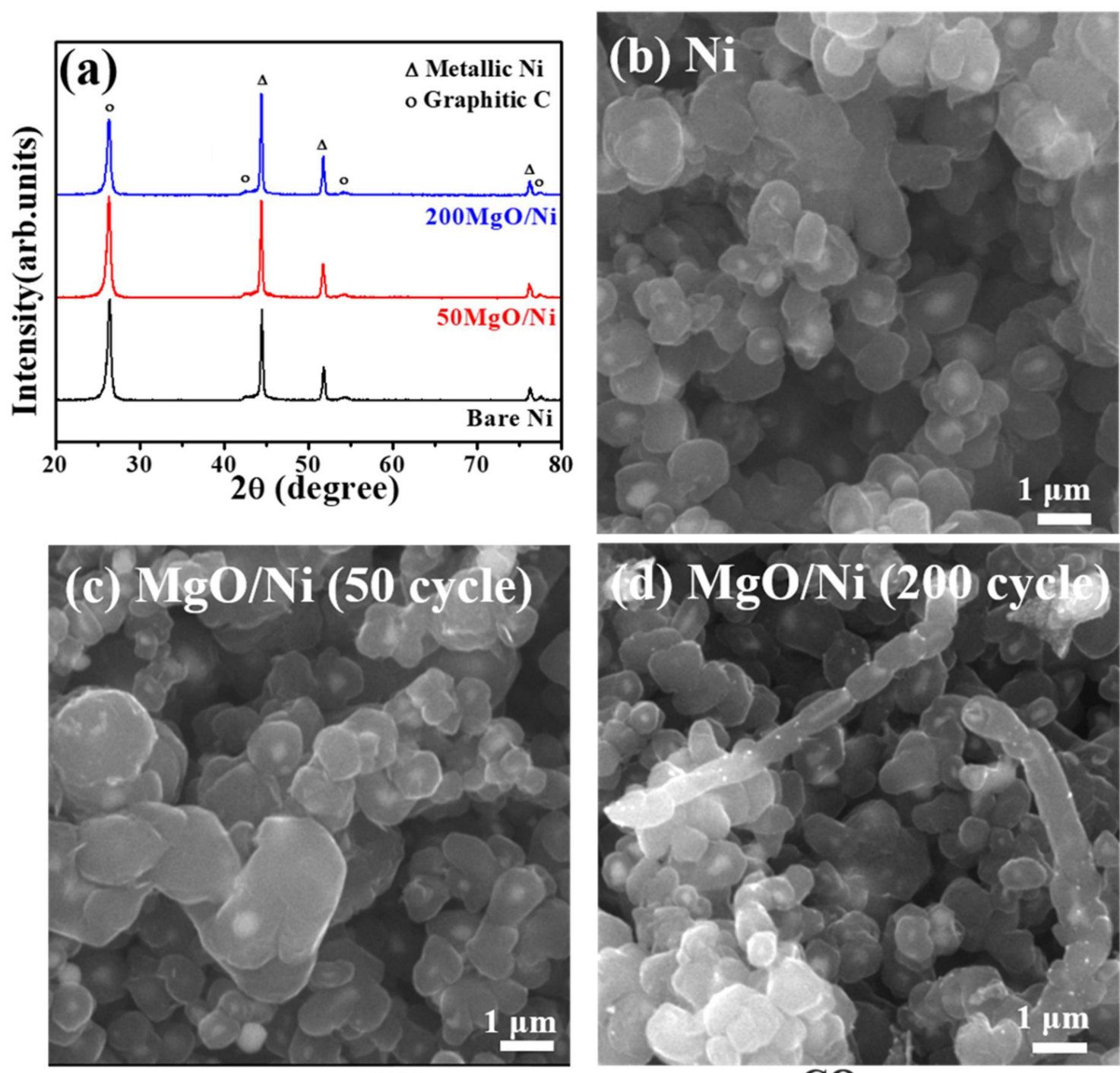

(e)
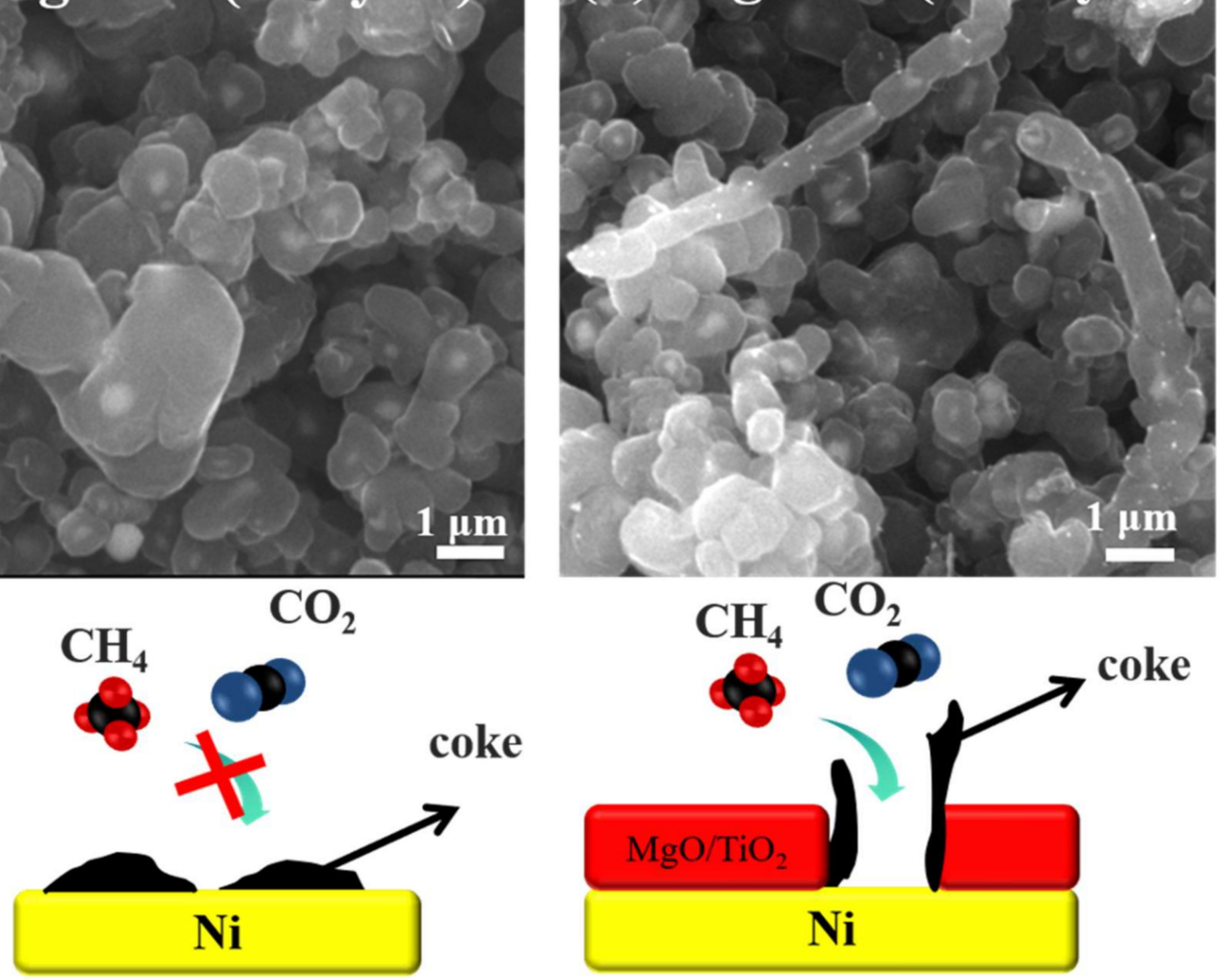

Figure 4. (a) X-ray diffraction (XRD) and (b-d) SEM results of bare and MgO-wrapped Ni particles after $72 \mathrm{~h}$ of the DRM reaction. (e) Schematic of the various deactivation behaviors. Edited from Reference [13].

Shells of thin layers of $\mathrm{TiO}_{2}$ (100 ALD cycles) and MgO (50 and 200 ALD cycles) on Ni showed improved DRM catalytic activity and stability. In terms of catalytic activity for the DRM reaction, $\mathrm{MgO} / \mathrm{Ni}$ is superior to $\mathrm{TiO}_{2} / \mathrm{Ni}$ both in terms of initial activity and long-term stability. The primary roles of $\mathrm{MgO}$ and $\mathrm{TiO}_{2}$ layers for enhancing DRM catalytic stability seem to be analogous to a geometric perturbation of coke formation by inducing carbon filament growth. $\mathrm{MgO}$ is a Lewis base, whereas $\mathrm{TiO}_{2}$ is not; therefore, $\mathrm{MgO}$ shows a higher affinity towards $\mathrm{CO}_{2}$, resulting in higher catalytic activity and stability for DRM $[13,31,37]$. This suggests that the chemical composition of the metal oxide shell is crucial to obtain a high catalytic activity for DRM. In order to further shed light on this issue, 
we recently performed the DRM reaction with $\mathrm{ZnO}$-wrapped Ni catalysts and showed (Figure 5) that the $\mathrm{ZnO}$ layer increases the deactivation of $\mathrm{Ni}$ catalyst during the DRM reaction. It is likely that $\mathrm{ZnO}$ layers induce a more facile formation of the coke layer on $\mathrm{Ni}$, which clearly demonstrates that to obtain a high-performing shell-core-type catalyst for DRM, not only the geometric structure of the metal oxide shell/Ni core is beneficial, but the chemical composition and thickness of the oxide shell are crucial. The influence of the chemical nature of metal oxide supports, such as acidity/basicity and reducibility, on the catalytic behaviors of metal particles towards the DRM reaction has been highlighted by many researchers. For instance, basic sites existing on metal oxides such as $\mathrm{La}_{2} \mathrm{O}_{3}$ and $\mathrm{MgO}$ can enhance the activation of $\mathrm{CO}_{2}$, which can reduce carbon formation and catalyst deactivation [96]. On the other hand, some research groups demonstrated that $\mathrm{CO}_{2}$ activation can also take place on acidic metal oxides via reaction with hydroxyls on the surface of acidic supports, but $\mathrm{CO}_{2}$ activation on acidic supports is weaker than that on basic supports $[28,97,98]$. The catalytic DRM reaction of Rh catalysts supported on various reducible and irreducible metal oxides was examined and the irreducible metal oxide supports generally led to higher catalytic activity of the supported metal catalyst than in the case of irreducible metal oxide supports [96]. However, it has also been reported that reducible $\mathrm{CeO}_{2}$ can promote the catalytic activity of the Ni catalysts for DRM reaction by acting as an oxygen accumulator [99].

(a)

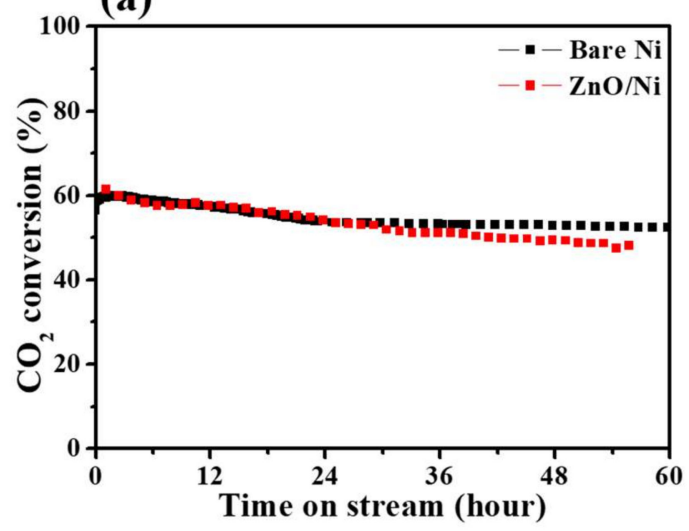

(b)

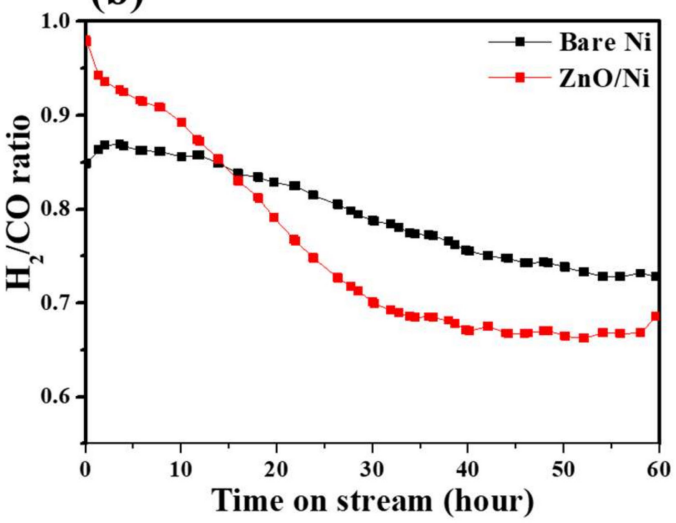

Figure 5. (a) $\mathrm{CO}_{2}$ conversion and (b) ratio of $\mathrm{H}_{2}$ to $\mathrm{CO}$, which are products of the DRM reaction, for bare $\mathrm{Ni}$ and $\mathrm{ZnO}$-wrapped $\mathrm{Ni}$. The DRM reactions were carried out at $800{ }^{\circ} \mathrm{C}$ under atmospheric conditions with a constant flow of the gas mixture $\left(\mathrm{CH}_{4}: \mathrm{CO}_{2}=1: 1\right.$, total flow rate of $\left.20 \mathrm{~mL} / \mathrm{min}\right)$.

Considering that ALD is able to finely tune the oxide film thickness and can be applied for a wide range of oxide materials, ALD can be regarded as a proper technique for obtaining highly efficient DRM catalysts. It should be emphasized that when the oxide shell becomes much thicker than the oxide shells presented here, collision of $\mathrm{CO}_{2}$ and $\mathrm{CH}_{4}$ with the $\mathrm{Ni}$ surface could be hindered and the catalysts will become less active. It is promising that the catalytic activity of metal particles for reactions other than DRM can be also finely controlled by adopting diverse structures of metal oxide shells on catalytically active metal particles, which can be realized by employing ALD.

\section{DRM Catalysts Consisting of Nanoparticles Implemented in a Mesoporous Template Prepared by ALD}

When ALD is used for depositing materials into a pre-formed mesoporous template, one can often observe the formation of nanoparticles confined in the mesopores instead of formation of homogeneous layers on the internal walls of mesoporous substrates. Nanoparticles are formed not only at the outermost surfaces of mesoporous particles with a diameter around several micrometers, but also in the deeper areas of mesoporous particles far from the particle surface. This can be achieved due to the high trench-fill capability of ALD. As shown in Figure 6, Pt was deposited on carbon aerogel substrate-formed nanoparticles with a mean diameter of 1-2 $\mathrm{nm}$ and these structures were shown to be extremely active for CO oxidation [100]. 


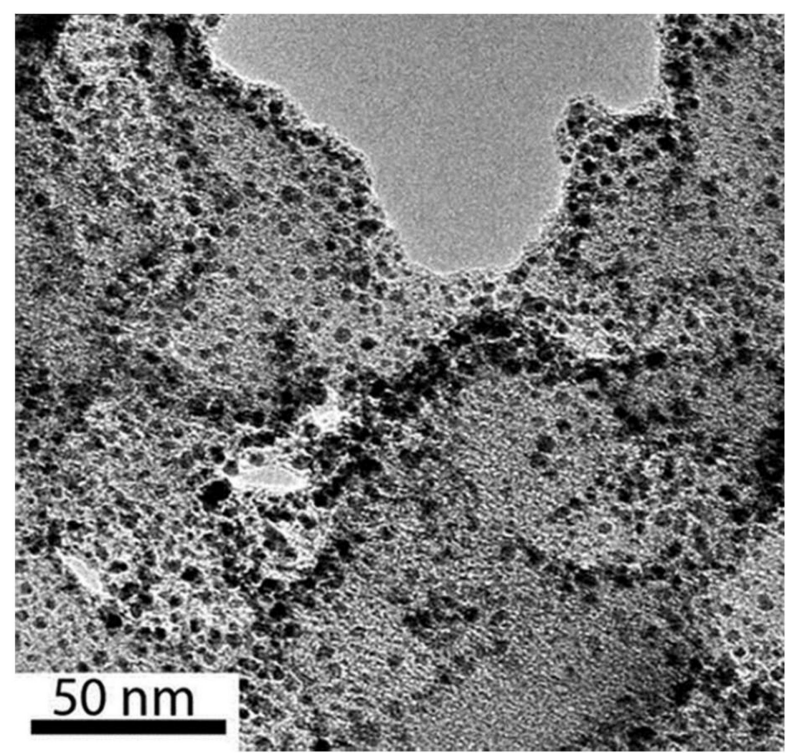

Figure 6. TEM image of Pt nanoparticles deposited in carbon aerogel by employing ALD. Reprinted with permission from Reference [100]. Copyright (2008) ACS Publications.

In the case of a metal-organic-framework (MOF), a NiO layer deposited into MIL-101(Cr) by employing ALD resulted in an almost unchanged pattern of pore size distribution compared to that before $\mathrm{NiO}$ deposition, where only the total pore volume decreased upon ALD of $\mathrm{NiO}$ (Figure 7) [101]. This result implies that some pores of MOF were clogged by NiO nanoparticles, whereas other pores were barely decorated by $\mathrm{NiO}$. The result in Figure 7 also confirms $\mathrm{NiO}$ decoration of not only the outermost surface of the MOF particles with a mean size of several hundred nanometers but also a substantially large portion of their internal pores.

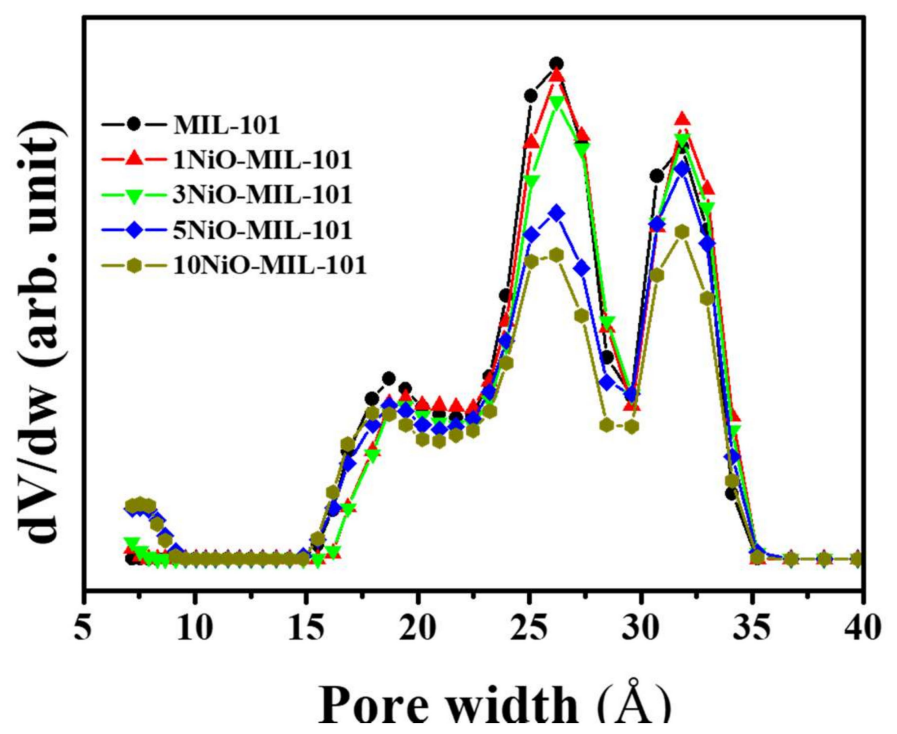

Figure 7. Pore-size distribution of MIL-101 with an increasing number of ALD cycles of NiO deposition. Reprinted with permission from Reference [101]. Copyright (2016) Elsevier.

For layer-by-layer deposition of thin films on the internal wall of mesoporous substrates, smaller micropores with a dimension of less than $1 \mathrm{~nm}$ can be easily clogged in the early stages of ALD with only several deposition cycles, which would further inhibit incorporation of materials into the deeper parts of mesoporous particles by additional ALD. It is possible to load a substantially large amount of additional materials into a mesoporous substrate since some pores are occupied by additional ALD 
materials, whereas others remain vacant. These vacant pores serve as diffusion channels of precursor vapor into the deeper parts of mesoporous particles. It seems that, at the very initial stage of ALD, some deposited materials form small seeds and a subsequent increase in the number of ALD cycles results in nucleation at the seeds, whereas other vacant places remain unoccupied. In an ideal situation with a relatively strong chemical interaction between the substrate and thin films, a layer-by-layer growth mode should be valid and one can observe atomically homogeneous and conformal thin film formation on the substrate surface $[55,60,62,102]$. In this case, one cannot easily understand the formation of nanoparticles inside mesoporous materials. However, it is well-known that the growth of thin films can change depending on the substrate-film interaction. With a moderate interaction between the film layer and substrate, the Stranski-Krastanov mode with monolayer formation followed by three-dimensional island formation can be found. With an even weaker film-substrate interaction, three-dimensional growth of a film from the earliest stage of deposition is found and is referred to as the Volmer-Weber growth mode (Figure 8b) [103]. It is often assumed that the ALD process results in layer-by-layer growth of thin films. However, detailed studies of thin film growth on the nanometer scale show diverse growth modes of thin films by employing ALD $[88,104]$.
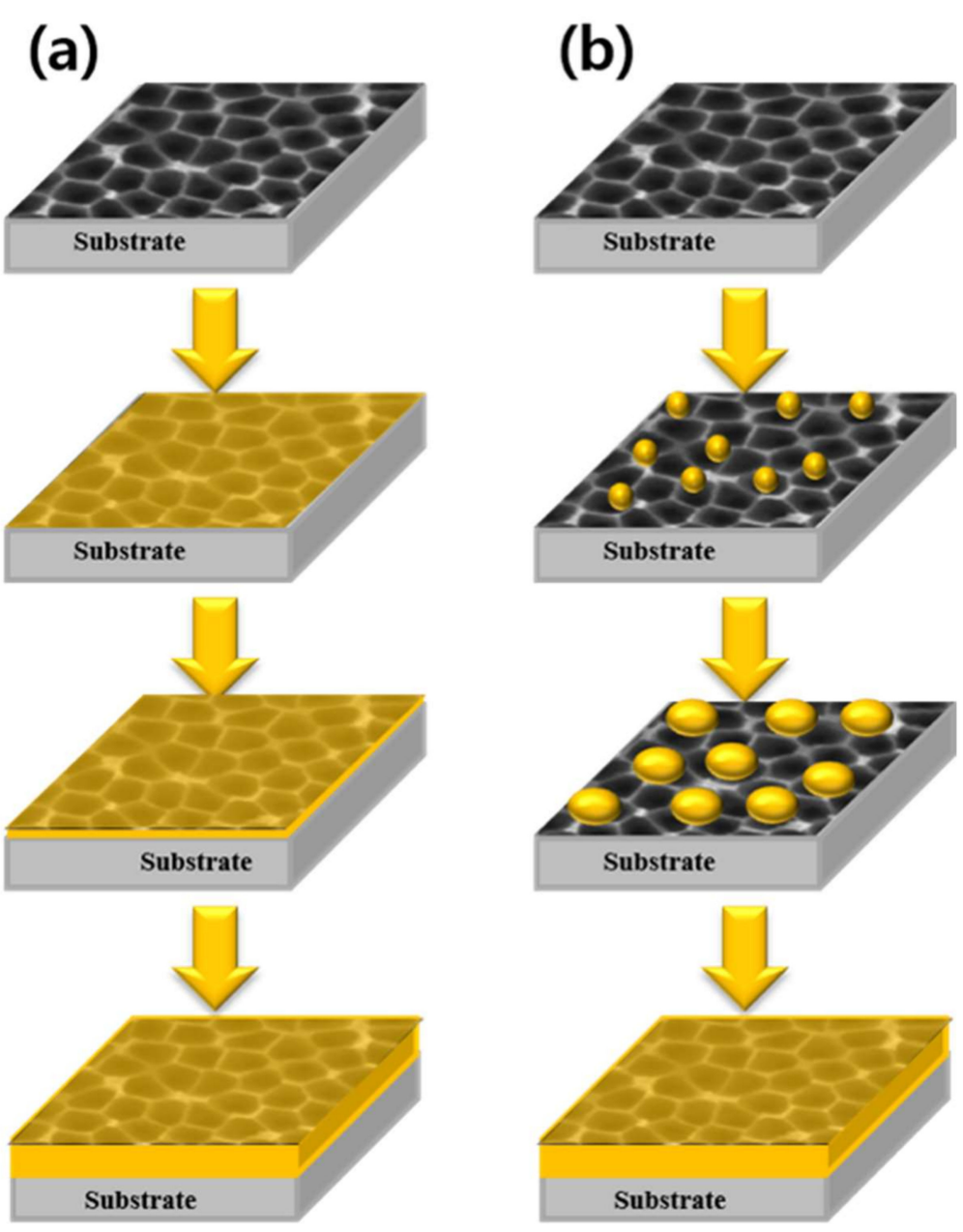

Figure 8. Schematic illustration of thin film growth based on (a) Frank-van der Merwe and (b) Volmer-weber modes.

$\mathrm{NiO}$ nanoparticles were prepared inside commercially available mesoporous silica using 50 ALD cycles and the resulting structure was used as a catalyst for DRM $[57,58]$. Mesoporous silica with a mean pore size of $\sim 12 \mathrm{~nm}$ and a pore size distribution from 2-20 nm was purchased from Sigma Aldrich and used as the mesoporous supporting materials. $\mathrm{NiO}$ nanoparticles were randomly distributed in a $\sim 10 \mu \mathrm{m}$ slab from the outermost surface part of the silica beads, demonstrating that ALD shows 
excellent trench fill capability. The amount of Ni loading was $2.9 \mathrm{wt} . \%$, which was determined using inductively coupled plasma-optical emission spectrometry (ICP-OES) [105].

The DRM reaction was conducted with $\mathrm{NiO}$ nanoparticles embedded into mesoporous silica at $800{ }^{\circ} \mathrm{C}$ using a horizontal fixed-bed quartz reactor [57]. For this, $0.1 \mathrm{~g}$ of Ni/SiO${ }_{2}$ catalyst was loaded on a ceramic holder and the holder was placed in the center of the quartz reactor. The gas mixture of $\mathrm{CH}_{4}$ and $\mathrm{CO}_{2}$ with a 1:1 mixing ratio was continuously fed into the reactor and the total flow rate was $20 \mathrm{~mL} / \mathrm{min}$ [57]. For comparison, the DRM reaction was also carried out with non-supported $\mathrm{Ni}$ particles $(<1 \mu \mathrm{m})$ under the same experimental conditions.

As shown in Figure 9a,b, the ALD-prepared Ni/silica exhibited higher catalytic activity and stability in terms of reactant $\left(\mathrm{CH}_{4}\right.$ and $\left.\mathrm{CO}_{2}\right)$ conversion and $\mathrm{CO}$ evolution ratio compared to non-supported catalysts (Ni particles). These results were attributed to the confined Ni particle size to less than $10 \mathrm{~nm}$ in the mesoporous substrate during the DRM reaction at $800{ }^{\circ} \mathrm{C}$ (Figure 9c). Even when the reaction time was extended to $168 \mathrm{~h}$ (7 days) at $800{ }^{\circ} \mathrm{C}$, the catalytic activity of the ALD-prepared $\mathrm{Ni}$ /silica catalysts remained at almost the same level, showing excellent catalytic stability (Figure 9d).
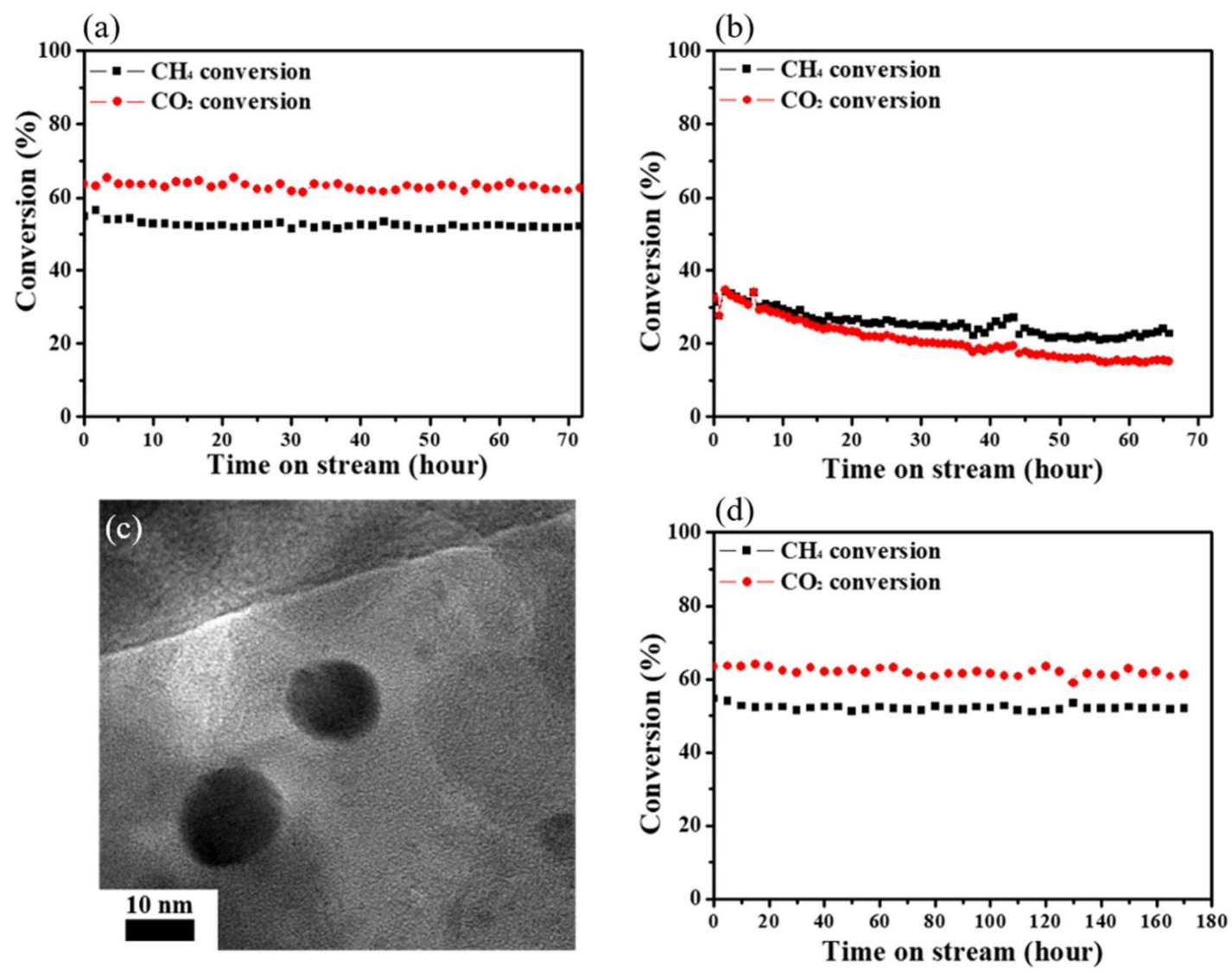

Figure 9. (a) $\mathrm{CH}_{4}$ and $\mathrm{CO}_{2}$ conversions of $\mathrm{Ni} /$ Silica catalyst at $800{ }^{\circ} \mathrm{C}$ for $72 \mathrm{~h}$. (b) $\mathrm{CH}_{4}$ and $\mathrm{CO}_{2}$ conversions of Ni catalyst at $800{ }^{\circ} \mathrm{C}$ for $72 \mathrm{~h}$. (c) TEM image of Ni/silica obtained after $72 \mathrm{~h}$ of the DRM reaction. (d) $\mathrm{CH}_{4}$ and $\mathrm{CO}_{2}$ conversions of the $\mathrm{Ni} /$ silica catalyst at $800{ }^{\circ} \mathrm{C}$ for $168 \mathrm{~h}$ (7 days). Edited from Reference [57].

It is interesting to note that coke formation was suppressed in the Ni nanoparticles confined in the mesopores, most likely due to the small nanoparticles with high curvature not showing high efficiency for two-dimensional graphitic carbon formation on Ni nanoparticles. This size-confinement effect on the catalytic activity and stability of Ni nanoparticles has been also reported elsewhere [27]. Recently, many scientific investigations were carried out to realize the effective incorporation of Ni nanoparticles inside porous substrates. 
$\mathrm{Ni}$ nanoparticles can also be embedded into the pores of porous substrates utilizing conventional wet methods such as impregnation or co-precipitation. Recently, some research groups managed to improve the efficiency of selective dispersion of $\mathrm{Ni}$ nanoparticles at the interior of the mesoporous structure by modifying classical impregnation methods $[106,107]$. However, it has been shown that the formation of Ni particles outside of pores is not avoidable during the wet chemical process [106,107]. It is important to mention that the catalytic activity and stability can be influenced by experimental conditions (amount of catalyst used, reactor design, temperature, gas mixing ratio, and total gas flow). Therefore, direct comparison of the catalytic performances of catalysts (e.g., Ni nanoparticles prepared by ALD vs. Ni nanoparticles prepared via a wet chemical method) reported in various literature is only meaningful if the experimental conditions are comparable. Recently, Gould et al. prepared dispersed Ni nanoparticles on porous alumina supports using either ALD or an incipient wetness (IW) process and their catalytic performances towards the DRM reaction at $600{ }^{\circ} \mathrm{C}$ were compared [32]. The ALD-prepared catalyst showed a higher rate of $\mathrm{CH}_{4}$ reforming and stability over IW-prepared catalysts under the same experimental conditions, which was attributed to better dispersion and the smaller size of ALD-prepared Ni nanoparticles than those prepared by the IW process [32]. Shang et al. also reported similar results showing higher catalytic activity and stability of ALD-prepared $\mathrm{Ni}$ nanoparticles on porous alumina than IW-prepared Ni nanoparticles on porous alumina in the temperature range of 700 to $850{ }^{\circ} \mathrm{C}$ [108]. It was also suggested that the interaction between ALD-prepared Ni nanoparticles and supports was stronger than in IW-prepared Ni nanoparticles cases considering that smaller Ni nanoparticles were formed by ALD compared to the IW method.

Figure 10 shows the $\mathrm{CH}_{4}$ and $\mathrm{CO}_{2}$ conversion of Ni nanoparticles supported by mesoporous $\mathrm{TiO}_{2}$ and alumina (Sasol, mean pore size of $11.6 \mathrm{~nm}$ ) during the $\mathrm{DRM}$ reaction at $800{ }^{\circ} \mathrm{C}$. $\mathrm{Ni} / \mathrm{TiO}_{2}$ and $\mathrm{Ni}$ /alumina catalysts were prepared by applying 50 ALD cycles for $\mathrm{NiO}$ deposition on mesoporous $\mathrm{TiO}_{2}$ and alumina, respectively. The mesoporous $\mathrm{TiO}_{2}$ substrate was prepared by depositing $\mathrm{TiO}_{2}$ thin films on mesoporous silica (Sigma Aldrich, mean pore diameter of $\sim 12 \mathrm{~nm}$ ) using the ALD technique, whereas mesoporous alumina with a mean pore diameter of $\sim 11.6 \mathrm{~nm}$ was used as purchased (Sasol). The DRM reactions were conducted at $800{ }^{\circ} \mathrm{C}$ in a fixed-bed quartz reactor with $0.1 \mathrm{~g}$ of Ni/TiO 2 and $\mathrm{Ni}$ /alumina catalysts. The $\mathrm{CH}_{4}$ and $\mathrm{CO}_{2}$ gas mixture at a 1:1 ratio was fed into the reactor and the total flow rate was $20 \mathrm{~mL} / \mathrm{min}$. Ni particles supported by mesoporous silica, $\mathrm{TiO}_{2}$, and alumina showed very similar activities and stabilities for the DRM catalytic reaction. This indicates that for $\mathrm{Ni}$ nanoparticle catalysts $(\sim 10 \mathrm{~nm})$ supported by a stable mesoporous substrate, the chemical composition of the substrate is less important for the catalytic behavior of $\mathrm{Ni}$ nanoparticles than the size of $\mathrm{Ni}$ nanoparticles confined by a porous structure of supporting materials [58].

(a)

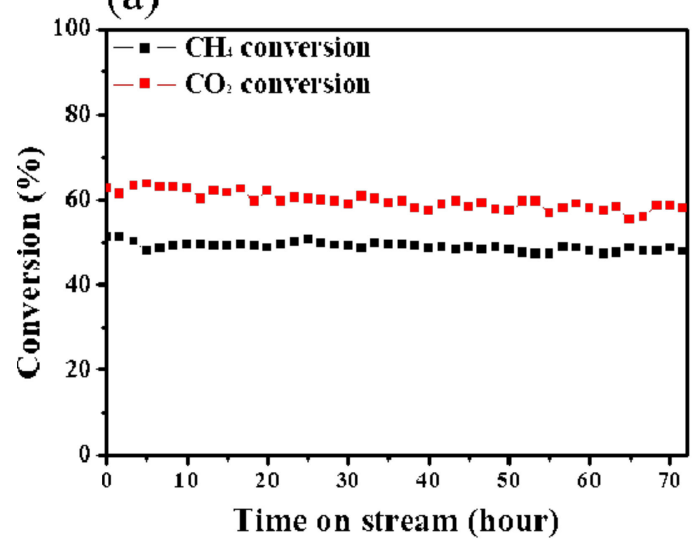

(b)

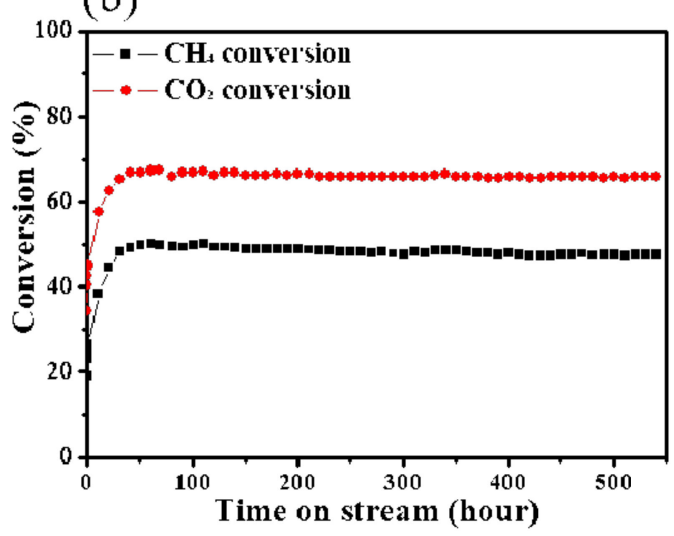

Figure 10. (a) $\mathrm{CH}_{4}$ and $\mathrm{CO}_{2}$ conversion of $\mathrm{Ni} / \mathrm{TiO}_{2}$ catalysts at $800{ }^{\circ} \mathrm{C}$ for $72 \mathrm{~h}$. (b) $\mathrm{CH}_{4}$ and $\mathrm{CO}_{2}$ conversion of $\mathrm{Ni}$ /alumina at $800{ }^{\circ} \mathrm{C}$ for $550 \mathrm{~h}$. The DRM reactions were carried out at $800{ }^{\circ} \mathrm{C}$ under atmospheric conditions with a constant flow of the gas mixture $\left(\mathrm{CH}_{4}: \mathrm{CO}_{2}=1: 1\right.$, total flow rate of $20 \mathrm{~mL} / \mathrm{min}$ ). Edited from Reference [57]. 


\section{Summary and Outlook}

ALD can be utilized to deposit thin films with diverse chemical compositions. The important specifications of ALD, which are not available in other thin film deposition methods such as physical vapor deposition, CVD, and wet-chemical coating methods, include its highly efficient trench-fill capability and fine control of film thickness on the atomic scale. These characteristics are beneficial for preparing various heterogeneous catalyst structures, particularly those active for the DRM reaction at $800{ }^{\circ} \mathrm{C}$. As an example, $\mathrm{MgO}$ - or $\mathrm{TiO}_{2}$-wrapped $\mathrm{Ni}$ sub-micrometer-sized particles with an oxide shell thickness of $\sim 20 \mathrm{~nm}$ were shown to be catalytically more active and stable for the DRM reaction compared to bare $\mathrm{Ni}$ particles or those wrapped with thinner oxide films. It was shown that these oxide shells suppressed coke formation on Ni surfaces, whereas cracks existing within these oxide shells are important for facile diffusion of reactant molecules $\left(\mathrm{CH}_{4}\right.$ and $\left.\mathrm{CO}_{2}\right)$ onto the Ni surfaces. Also, ALD was used to deposit Ni nanoparticles into the deep parts of mesoporous particles and the Ni nanoparticles incorporated into a mesoporous substrate were highly resistant towards sintering and coke formation. As a result, they are more catalytically active and stable for the DRM reaction. These unique catalyst structures, either oxide shell-wrapped metal particles or metal nanoparticles incorporated into mesoporous oxide substrates, prepared by ALD can help explain catalytic behaviors of variously structured heterogeneous catalysts.

In terms of practical application of heterogeneous catalysts, ALD is regarded to be less effective for mass-scale production of catalysts, even if its use can produce various interesting catalyst structures which are otherwise difficult to achieve. In order to overcome the disadvantages of ALD for mass production, methods such as temperature-regulated chemical vapor deposition have been developed and considered for preparing heterogeneous catalysts, whose structures are comparable to those prepared by ALD [109-113]. ALD is probably not a method which can be ultimately used in the mass production of heterogeneous catalysts, yet studies of ALD-prepared catalysts can shed light on the structure-function relationship in heterogeneous catalysts owing to the ability of ALD to finely tune the structure of catalysts.

Author Contributions: S.Y.K. analyzed the catalytic performance data of the shell-core type catalysts. S.Y.K., B.J.C., and S.S. carried out the literature review and writing of the manuscript. H.O.S. and Y.D.K. wrote the manuscript and supervised the study.

Funding: This research was supported by the Basic Science Research Program through the National Research Foundation of Korea (NRF) funded by the Ministry of Education (2018R1D1A1B07040916), and by a research grant from the Korea Basic Science Institute (D39613).

Conflicts of Interest: The authors declare no conflicts of interest.

\section{References}

1. Bowes, G. Facing the inevitable: Plants and increasing atmospheric $\mathrm{CO}_{2}$. Annu. Rev. Plant Physiol. Plant Mol. Biol. 1993, 44, 309-332. [CrossRef]

2. Yang, H.; Xu, Z.; Fan, M.; Gupta, R.; Slimane, R.B.; Bland, A.E.; Wright, I. Progress in carbon dioxide separation and capture: A review. J. Environ. Sci. 2008, 20, 14-27. [CrossRef]

3. King, A.W.; Emanuel, W.R.; Post, W.M. Projecting future concentrations of atmospheric $\mathrm{CO}_{2}$ with global carbon cycle models: The importance of simulating historical changes. Environ. Manag. 1992, 16, 91-108. [CrossRef]

4. Sozzani, P.; Bracco, S.; Comotti, A.; Ferretti, L.; Simonutti, R. Methane and carbon dioxide storage in a porous van der waals crystal. Angew. Chem. Int. Ed. 2005, 44, 1816-1820. [CrossRef] [PubMed]

5. Liu, J.; Thallapally, P.K.; McGrail, B.P.; Brown, D.R.; Liu, J. Progress in adsorption-based CO-2 capture by metal-organic frameworks. Chem. Soc. Rev. 2012, 41, 2308-2322. [CrossRef] [PubMed]

6. Liu, Y.; Wang, Z.U.; Zhou, H.-C. Recent advances in carbon dioxide capture with metal-organic frameworks. Greenh. Gases 2012, 2, 239-259. [CrossRef]

7. Sumida, K.; Rogow, D.L.; Mason, J.A.; McDonald, T.M.; Bloch, E.D.; Herm, Z.R.; Bae, T.-H.; Long, J.R. Carbon dioxide capture in metal-organic frameworks. Chem. Rev. 2012, 112, 724-781. [CrossRef] [PubMed] 
8. Li, J.-R.; Ma, Y.; McCarthy, M.C.; Sculley, J.; Yu, J.; Jeong, H.-K.; Balbuena, P.B.; Zhou, H.-C. Carbon dioxide capture-related gas adsorption and separation in metal-organic frameworks. Coord. Chem. Rev. 2011, 255, 1791-1823. [CrossRef]

9. Li, J.-R.; Kuppler, R.J.; Zhou, H.-C. Selective gas adsorption and separation in metal-organic frameworks. Chem. Soc. Rev. 2009, 38, 1477-1504. [CrossRef] [PubMed]

10. Wang, S.; Yan, S.; Ma, X.; Gong, J. Recent advances in capture of carbon dioxide using alkali-metal-based oxides. Energy Environ. Sci. 2011, 4, 3805-3819. [CrossRef]

11. Bhagiyalakshmi, M.; Lee, J.Y.; Jang, H.T. Synthesis of mesoporous magnesium oxide: Its application to $\mathrm{CO}_{2}$ chemisorption. Int. J. Greenh. Gas Control 2010, 4, 51-56. [CrossRef]

12. Millward, A.R.; Yaghi, O.M. Metal-organic frameworks with exceptionally high capacity for storage of carbon dioxide at room temperature. J. Am. Chem. Soc. 2005, 127, 17998-17999. [CrossRef] [PubMed]

13. Jeong, M.-G.; Kim, S.Y.; Kim, D.H.; Han, S.W.; Kim, I.H.; Lee, M.; Hwang, Y.K.; Kim, Y.D. High-performing and durable $\mathrm{MgO} / \mathrm{Ni}$ catalysts via atomic layer deposition for $\mathrm{CO}_{2}$ reforming of methane (CRM). Appl. Catal. A 2016, 515, 45-50. [CrossRef]

14. Kortlever, R.; Shen, J.; Schouten, K.J.P.; Calle-Vallejo, F.; Koper, M.T.M. Catalysts and reaction pathways for the electrochemical reduction of carbon dioxide. J. Phys. Chem. Lett. 2015, 6, 4073-4082. [CrossRef] [PubMed]

15. Jitaru, M.; Lowy, D.A.; Toma, M.; Toma, B.C.; Oniciu, L. Electrochemical reduction of carbon dioxide on flat metallic cathodes. J. Appl. Electrochem. 1997, 27, 875-889. [CrossRef]

16. Gattrell, M.; Gupta, N.; Co, A. A review of the aqueous electrochemical reduction of $\mathrm{CO}_{2}$ to hydrocarbons at copper. J. Electroanal. Chem. 2006, 594, 1-19. [CrossRef]

17. Roy, S.C.; Varghese, O.K.; Paulose, M.; Grimes, C.A. Toward solar fuels: Photocatalytic conversion of carbon dioxide to hydrocarbons. ACS Nano 2010, 4, 1259-1278. [CrossRef] [PubMed]

18. Darensbourg, D.J.; Holtcamp, M.W. Catalysts for the reactions of epoxides and carbon dioxide. Coord. Chem. Rev. 1996, 153, 155-174. [CrossRef]

19. Darensbourg, D.J. Making plastics from carbon dioxide: Salen metal complexes as catalysts for the production of polycarbonates from epoxides and $\mathrm{CO}_{2}$. Chem. Rev. 2007, 107, 2388-2410. [CrossRef] [PubMed]

20. Omae, I. Recent developments in carbon dioxide utilization for the production of organic chemicals. Coord. Chem. Rev. 2012, 256, 1384-1405. [CrossRef]

21. Wang, W.; Wang, S.; Ma, X.; Gong, J. Recent advances in catalytic hydrogenation of carbon dioxide. Chem. Soc. Rev. 2011, 40, 3703-3727. [CrossRef] [PubMed]

22. Saeidi, S.; Amin, N.A.S.; Rahimpour, M.R. Hydrogenation of $\mathrm{CO}_{2}$ to value-added products-A review and potential future developments. J. $\mathrm{CO}_{2}$ Util. 2014, 5, 66-81. [CrossRef]

23. Ma, J.; Sun, N.; Zhang, X.; Zhao, N.; Xiao, F.; Wei, W.; Sun, Y. A short review of catalysis for $\mathrm{CO}_{2}$ conversion. Catal. Today 2009, 148, 221-231. [CrossRef]

24. Soltanieh, M.; Azar, K.M.; Saber, M. Development of a zero emission integrated system for co-production of electricity and methanol through renewable hydrogen and $\mathrm{CO}_{2}$ capture. Int. J. Greenh. Gas Control 2012, 7, 145-152. [CrossRef]

25. Talebian-Kiakalaieh, A.; Amin, N.A.S.; Mazaheri, H. A review on novel processes of biodiesel production from waste cooking oil. Appl. Energy 2013, 104, 683-710. [CrossRef]

26. Aresta, M.; Dibenedetto, A.; Angelini, A. The changing paradigm in $\mathrm{CO}_{2}$ utilization. J. $\mathrm{CO}_{2}$ Util. 2013, 3-4, 65-73. [CrossRef]

27. Seo, O.H. Recent scientific progress on developing supported Ni catalysts for dry $\left(\mathrm{CO}_{2}\right)$ reforming of methane. Catalysts 2018, 8, 110. [CrossRef]

28. Pakhare, D.; Spivey, J. A review of dry $\left(\mathrm{CO}_{2}\right)$ reforming of methane over noble metal catalysts. Chem. Soc. Rev. 2014, 43, 7813-7837. [CrossRef] [PubMed]

29. Rostrupnielsen, J.R.; Hansen, J.H.B. $\mathrm{CO}_{2}$-reforming of methane over transition metals. J. Catal. 1993, 144, 38-49. [CrossRef]

30. Kim, D.H.; Kim, S.Y.; Han, S.W.; Cho, Y.K.; Jeong, M.-G.; Park, E.J.; Kim, Y.D. The catalytic stability of $\mathrm{TiO}_{2}$-shell/Ni-core catalysts for $\mathrm{CO}_{2}$ reforming of $\mathrm{CH}_{4}$. Appl. Catal. A 2015, 495, 184-191. [CrossRef]

31. García, V.; Fernández, J.J.; Ruíz, W.; Mondragón, F.; Moreno, A. Effect of MgO addition on the basicity of $\mathrm{Ni} / \mathrm{ZrO}_{2}$ and on its catalytic activity in carbon dioxide reforming of methane. Catal. Commun. 2009, 11, 240-246. [CrossRef] 
32. Gould, T.D.; Montemore, M.M.; Lubers, A.M.; Ellis, L.D.; Weimer, A.W.; Falconer, J.L.; Medlin, J.W. Enhanced dry reforming of methane on $\mathrm{Ni}$ and $\mathrm{Ni}$-Pt catalysts synthesized by atomic layer deposition. Appl. Catal. A 2015, 492, 107-116. [CrossRef]

33. Bradford, M.C.J.; Vannice, M.A. Catalytic reforming of methane with carbon dioxide over nickel catalysts I. Catalyst characterization and activity. Appl. Catal. A 1996, 142, 73-96. [CrossRef]

34. Kroll, V.C.H.; Swaan, H.M.; Mirodatos, C. Methane reforming reaction with carbon dioxide over $\mathrm{Ni} / \mathrm{SiO}_{2}$ catalyst: I. deactivation studies. J. Catal. 1996, 161, 409-422. [CrossRef]

35. Guczi, L.; Stefler, G.; Geszti, O.; Sajó, I.; Pászti, Z.; Tompos, A.; Schay, Z. Methane dry reforming with $\mathrm{CO}_{2}$ : A study on surface carbon species. Appl. Catal. A 2010, 375, 236-246. [CrossRef]

36. Liu, C.-J.; Ye, J.; Jiang, J.; Pan, Y. Progresses in the preparation of coke resistant Ni-based catalyst for steam and $\mathrm{CO}_{2}$ reforming of methane. ChemCatChem 2011, 3, 529-541. [CrossRef]

37. Bouarab, R.; Akdim, O.; Auroux, A.; Cherifi, O.; Mirodatos, C. Effect of MgO additive on catalytic properties of $\mathrm{Co} / \mathrm{SiO}_{2}$ in the dry reforming of methane. Appl. Catal. A 2004, 264, 161-168. [CrossRef]

38. Xu, L.; Song, H.; Chou, L. One-pot synthesis of ordered mesoporous $\mathrm{NiO}-\mathrm{CaO}-\mathrm{Al}_{2} \mathrm{O}_{3}$ composite oxides for catalyzing $\mathrm{CO}_{2}$ reforming of $\mathrm{CH}_{4}$. ACS Catal. 2012, 2, 1331-1342. [CrossRef]

39. Wang, S.-G.; Liao, X.-Y.; Cao, D.-B.; Huo, C.-F.; Li, Y.-W.; Wang, J.; Jiao, H. Factors controlling the Interaction of $\mathrm{CO}_{2}$ with transition metal surfaces. J. Phys. Chem. C 2007, 111, 16934-16940. [CrossRef]

40. Quincoces, C.E.; Dicundo, S.; Alvarez, A.M.; González, M.G. Effect of addition of $\mathrm{CaO}$ on $\mathrm{Ni} / \mathrm{Al}_{2} \mathrm{O}_{3}$ catalysts over $\mathrm{CO}_{2}$ reforming of methane. Mater. Lett. 2001, 50, 21-27. [CrossRef]

41. Baudouin, D.; Rodemerck, U.; Krumeich, F.; Mallmann, A.D.; Szeto, K.C.; Ménard, H.; Veyre, L.; Candy, J.-P.; Webb, P.B.; Thieuleux, C.; et al. Particle size effect in the low temperature reforming of methane by carbon dioxide on silica-supported Ni nanoparticles. J. Catal. 2013, 297, 27-34. [CrossRef]

42. Luisetto, I.; Tuti, S.; Battocchio, C.; Lo Mastro, S.; Sodo, A. Ni/CeO $\mathrm{Cl}_{2}-\mathrm{Al}_{2} \mathrm{O}_{3}$ catalysts for the dry reforming of methane: The effect of $\mathrm{CeAlO}_{3}$ content and nickel crystallite size on catalytic activity and coke resistance. Appl. Catal. A 2015, 500, 12-22. [CrossRef]

43. Kim, J.-H.; Suh, D.J.; Park, T.-J.; Kim, K.-L. Effect of metal particle size on coking during $\mathrm{CO}_{2}$ reforming of $\mathrm{CH}_{4}$ over Ni-alumina aerogel catalysts. Appl. Catal. A 2000, 197, 191-200. [CrossRef]

44. Slagtern, s.; Olsbye, U.; Blom, R.; Dahl, I.M. The influence of rare earth oxides on $\mathrm{Ni} / \mathrm{Al}_{2} \mathrm{O}_{3}$ catalysts during $\mathrm{CO}_{2}$ reforming of $\mathrm{CH}_{4}$. Stud. Surf. Sci. Catal. 1997, 107, 497-502.

45. Wang, S.; Lu, G.Q. Reforming of methane with carbon dioxide over $\mathrm{Ni} / \mathrm{Al}_{2} \mathrm{O}_{3}$ catalysts: Effect of nickel precursor. Appl. Catal. A 1998, 169, 271-280. [CrossRef]

46. Lemonidou, A.A.; Vasalos, I.A. Carbon dioxide reforming of methane over 5 wt. $\% \mathrm{Ni} / \mathrm{CaO}-\mathrm{Al}_{2} \mathrm{O}_{3}$ catalyst. Appl. Catal. A 2002, 228, 227-235. [CrossRef]

47. Sneh, O.; Clark-Phelps, R.B.; Londergan, A.R.; Winkler, J.; Seidel, T.E. Thin film atomic layer deposition equipment for semiconductor processing. Thin Solid Films 2002, 402, 248-261. [CrossRef]

48. Kim, H. Atomic layer deposition of metal and nitride thin films: Current research efforts and applications for semiconductor device processing. J. Vac. Sci. Technol. B 2003, 21, 2231-2261. [CrossRef]

49. Sheng, J.; Han, K.-L.; Hong, T.; Choi, W.-H.; Park, J.-S. Review of recent progresses on flexible oxide semiconductor thin film transistors based on atomic layer deposition processes. J. Semicond. 2018, 39, 011008. [CrossRef]

50. Yan, B.; Li, X.; Bai, Z.; Song, X.; Xiong, D.; Zhao, M.; Li, D.; Lu, S. A review of atomic layer deposition providing high performance lithium sulfur batteries. J. Power Sources 2017, 338, 34-48. [CrossRef]

51. Palmstrom, A.F.; Santra, P.K.; Bent, S.F. Atomic layer deposition in nanostructured photovoltaics: Tuning optical, electronic and surface properties. Nanoscale 2015, 7, 12266-12283. [CrossRef] [PubMed]

52. Dasgupta, N.P.; Meng, X.; Elam, J.W.; Martinson, A.B.F. Atomic layer deposition of metal sulfide materials. Acc. Chem. Res. 2015, 48, 341-348. [CrossRef] [PubMed]

53. Sutherland, B.R.; Hoogland, S.; Adachi, M.M.; Kanjanaboos, P.; Wong, C.T.O.; McDowell, J.J.; Xu, J.; Voznyy, O.; Ning, Z.; Houtepen, A.J.; et al. Perovskite thin films via atomic layer deposition. Adv. Mater. 2015, 27, 53-58. [CrossRef] [PubMed]

54. O’Neill, B.J.; Jackson, D.H.K.; Lee, J.; Canlas, C.; Stair, P.C.; Marshall, C.L.; Elam, J.W.; Kuech, T.F.; Dumesic, J.A.; Huber, G.W. Catalyst design with atomic layer deposition. ACS Catal. 2015, 5, 1804-1825. [CrossRef] 
55. Marichy, C.; Bechelany, M.; Pinna, N. Atomic layer deposition of nanostructured materials for energy and environmental applications. Adv. Mater. 2012, 24, 1017-1032. [CrossRef] [PubMed]

56. Li, J.; Liang, X.; King, D.M.; Jiang, Y.-B.; Weimer, A.W. Highly dispersed Pt nanoparticle catalyst prepared by atomic layer deposition. Appl. Catal. B 2010, 97, 220-226. [CrossRef]

57. Kim, D.H.; Sim, J.K.; Lee, J.; Seo, H.O.; Jeong, M.-G.; Kim, Y.D.; Kim, S.H. Carbon dioxide reforming of methane over mesoporous $\mathrm{Ni} / \mathrm{SiO}_{2}$. Fuel 2013, 112, 111-116. [CrossRef]

58. Kim, D.H.; Seo, H.O.; Jeong, M.-G.; Kim, Y.D. Reactivity and stability of Ni nanoparticles supported by mesoporous $\mathrm{SiO}_{2}$ and $\mathrm{TiO}_{2} / \mathrm{SiO}_{2}$ for $\mathrm{CO}_{2}$ Reforming of $\mathrm{CH}_{4}$. Catal. Lett. 2014, 144, 56-61. [CrossRef]

59. Seo, H.O.; Sim, J.K.; Kim, K.-D.; Kim, Y.D.; Lim, D.C.; Kim, S.H. Carbon dioxide reforming of methane to synthesis gas over a $\mathrm{TiO}_{2}-\mathrm{Ni}$ inverse catalyst. Appl. Catal. A 2013, 451, 43-49. [CrossRef]

60. George, S.M. Atomic layer deposition: An overview. Chem. Rev. 2010, 110, 111-131. [CrossRef] [PubMed]

61. Johnson, R.W.; Hultqvist, A.; Bent, S.F. A brief review of atomic layer deposition: From fundamentals to applications. Mater. Today 2014, 17, 236-246. [CrossRef]

62. Ritala, M.; Leskelä, M.; Dekker, J.-P.; Mutsaers, C.; Soininen, P.J.; Skarp, J. Perfectly conformal TiN and $\mathrm{Al}_{2} \mathrm{O}_{3}$ films deposited by atomic layer deposition. Chem. Vap. Depos. 1999, 5, 7-9. [CrossRef]

63. Singh, J.A.; Yang, N.; Bent, S.F. Nanoengineering heterogeneous catalysts by atomic layer deposition. Annu. Rev. Chem. Biomol. Eng. 2017, 8, 41-62. [CrossRef] [PubMed]

64. Gao, Z.; Qin, Y. Design and properties of confined nanocatalysts by atomic layer deposition. Acc. Chem. Res. 2017, 50, 2309-2316. [CrossRef] [PubMed]

65. Leskelä, M.; Ritala, M. Atomic layer deposition (ALD): From precursors to thin film structures. Thin Solid Films 2002, 409, 138-146. [CrossRef]

66. Puurunen, R.L.; Vandervorst, W. Island growth as a growth mode in atomic layer deposition: A phenomenological model. J. Appl. Phys. 2004, 96, 7686-7695. [CrossRef]

67. Kim, J.-H.; Kim, J.-Y.; Kang, S.-W. Film growth model of atomic layer deposition for multicomponent thin films. J. Appl. Phys. 2005, 97, 093505. [CrossRef]

68. Aaltonen, T.; Alén, P.; Ritala, M.; Leskelä, M. Ruthenium thin films grown by atomic layer deposition. Chem. Vap. Depos. 2003, 9, 45-49. [CrossRef]

69. Lee, H.J.; Seo, H.O.; Kim, D.W.; Kim, K.-D.; Luo, Y.; Lim, D.C.; Ju, H.; Kim, J.W.; Lee, J.; Kim, Y.D. A high-performing nanostructured $\mathrm{TiO}_{2}$ filter for volatile organic compounds using atomic layer deposition. Chem. Commun. 2011, 47, 5605-5607. [CrossRef] [PubMed]

70. Park, J.S.; Mane, A.U.; Elam, J.W.; Croy, J.R. Amorphous metal fluoride passivation coatings prepared by atomic layer deposition on $\mathrm{LiCoO}_{2}$ for Li-ion batteries. Chem. Mater. 2015, 27, 1917-1920. [CrossRef]

71. Chang, C.-Y.; Lee, K.-T.; Huang, W.-K.; Siao, H.-Y.; Chang, Y.-C. High-performance, air-stable, low-temperature processed semitransparent perovskite solar cells enabled by atomic layer deposition. Chem. Mater. 2015, 27, 5122-5130. [CrossRef]

72. Kozen, A.C.; Lin, C.-F.; Pearse, A.J.; Schroeder, M.A.; Han, X.; Hu, L.; Lee, S.-B.; Rubloff, G.W.; Noked, M. Next-generation lithium metal anode engineering via atomic layer deposition. ACS Nano 2015, 9, 5884-5892. [CrossRef] [PubMed]

73. Kim, D.H.; Kim, Y.D. Oxidation behaviors of poly(3-hexylthiophene-2,5-diyl) on indium tin oxide surfaces without and with additional $\mathrm{TiO}_{2}$ thin films. Bull. Korean Chem. Soc. 2015, 36, 798-803.

74. Kim, D.H.; Jeong, M.-G.; Seo, H.O.; Kim, Y.D. Oxidation behavior of P3HT layers on bare and $\mathrm{TiO}_{2}$-covered $\mathrm{ZnO}$ ripple structures evaluated by photoelectron spectroscopy. Phys. Chem. Chem. Phys. 2015, 17, 599-604. [CrossRef] [PubMed]

75. Kim, K.-D.; Im, D.-C.; Jeong, M.-G.; Seo, H.O.; Seo, B.Y.; Lee, J.-Y.; Song, Y.-S.; Cho, S.; Lim, J.-H.; Kim, Y.D. Enhanced stability of organic photovoltaics by additional $\mathrm{ZnO}$ layers on rippled $\mathrm{ZnO}$ electron-collecting layer using atomic layer deposition. Bull. Korean Chem. Soc. 2014, 35, 353-356. [CrossRef]

76. Kim, K.-D.; Lim, D.C.; Hu, J.; Kwon, J.-D.; Jeong, M.-G.; Seo, H.O.; Lee, J.Y.; Jang, K.-Y.; Lim, J.-H.; Lee, K.H.; et al. Surface modification of a $\mathrm{ZnO}$ electron-collecting layer using atomic layer deposition to fabricate high-Performing inverted organic photovoltaics. ACS Appl. Mater. Interfaces 2013, 5, 8718-8723. [CrossRef] [PubMed]

77. Kim, K.-D.; Lim, D.C.; Seo, H.O.; Lee, J.Y.; Seo, B.Y.; Lee, D.J.; Song, Y.; Cho, S.; Lim, J.-H.; Kim, Y.D. Enhanced performance of organic photovoltaics by $\mathrm{TiO}_{2}$-interlayer with precisely controlled thickness between $\mathrm{ZnO}$ electron collecting and active layers. Appl. Surf. Sci. 2013, 279, 380-383. [CrossRef] 
78. Lim, D.C.; Kim, K.-D.; Park, S.-Y.; Hong, E.M.; Seo, H.O.; Lim, J.H.; Lee, K.H.; Jeong, Y.; Song, C.; Lee, E.; et al. Towards fabrication of high-performing organic photovoltaics: New donor-polymer, atomic layer deposited thin buffer layer and plasmonic effects. Energy Environ. Sci. 2012, 5, 9803-9807. [CrossRef]

79. Park, S.-Y.; Seo, H.O.; Kim, K.-D.; Shim, W.H.; Heo, J.; Cho, S.; Kim, Y.D.; Lee, K.H.; Lim, D.C. Organic solar cells fabricated by one-step deposition of a bulk heterojunction mixture and $\mathrm{TiO}_{2} / \mathrm{NiO}$ hole-collecting agents. J. Phys. Chem. C 2012, 116, 15348-15352. [CrossRef]

80. Park, S.-Y.; Seo, H.O.; Kim, K.-D.; Lee, J.E.; Kwon, J.-D.; Kim, Y.D.; Lim, D.C. Organic photovoltaics with high stability sustained for 100 days without encapsulation fabricated using atomic layer deposition. Phys. Status Solidi Rapid Res. Lett. 2012, 6, 196-198. [CrossRef]

81. Seo, H.O.; Sim, C.W.; Kim, K.-D.; Kim, Y.D.; Park, J.H.; Lee, B.C.; Lee, K.H.; Lim, D.C. Influence of high-energy electron-beam on photocatalytic activity of $\mathrm{TiO}_{2}$ films on carbon-fiber deposited by atomic layer deposition. Radiat. Phys. Chem. 2012, 81, 290-294. [CrossRef]

82. Kim, K.-D.; Dey, N.K.; Seo, H.O.; Kim, Y.D.; Lim, D.C.; Lee, M. Photocatalytic decomposition of toluene by nanodiamond-supported $\mathrm{TiO}_{2}$ prepared using atomic layer deposition. Appl. Catal. A 2011, 408, 148-155. [CrossRef]

83. Schwab, G.-M. Electronics of Supported Catalysts. Adv. Catal. 1979, 27, 1-22.

84. Rodríguez, J.A.; Hrbek, J. Inverse oxide/metal catalysts: A versatile approach for activity tests and mechanistic studies. Surf. Sci. 2010, 604, 241-244. [CrossRef]

85. Rodriguez, J.A.; Liu, P.; Graciani, J.; Senanayake, S.D.; Grinter, D.C.; Stacchiola, D.; Hrbek, J.; Fernández-Sanz, J. Inverse oxide/metal catalysts in fundamental studies and practical applications: A perspective of recent developments. J. Phys. Chem. Lett. 2016, 7, 2627-2639. [CrossRef] [PubMed]

86. Zhang, J.; Medlin, J.W. Catalyst design using an inverse strategy: From mechanistic studies on inverted model catalysts to applications of oxide-coated metal nanoparticles. Surf. Sci. Rep. 2018, 73, 117-152. [CrossRef]

87. Mahapatra, M.; Gutiérrez, R.A.; Kang, J.; Rui, N.; Hamlyn, R.; Liu, Z.; Orozco, I.; Ramírez, P.J.; Senanayake, S.D.; Rodriguez, J.A. The behavior of inverse oxide/metal catalysts: CO oxidation and water-gas shift reactions over $\mathrm{ZnO} / \mathrm{Cu}(111)$ surfaces. Surf. Sci. 2019, 681, 116-121. [CrossRef]

88. Dey, N.K.; Kim, M.J.; Kim, K.-D.; Seo, H.O.; Kim, D.; Kim, Y.D.; Lim, D.C.; Lee, K.H. Adsorption and photocatalytic degradation of methylene blue over $\mathrm{TiO}_{2}$ films on carbon fiber prepared by atomic layer deposition. J. Mol. Catal. A Chem. 2011, 337, 33-38. [CrossRef]

89. Barroso-Quiroga, M.M.; Castro-Luna, A.E. Catalytic activity and effect of modifiers on Ni-based catalysts for the dry reforming of methane. Int. J. Hydrogen Energy 2010, 35, 6052-6056. [CrossRef]

90. Ginsburg, J.M.; Piña, J.; El Solh, T.; de Lasa, H.I. Coke formation over a nickel catalyst under methane dry reforming conditions: Thermodynamic and kinetic models. Ind. Eng. Chem. Res. 2005, 44, 4846-4854. [CrossRef]

91. Chen, D.; Lødeng, R.; Anundskås, A.; Olsvik, O.; Holmen, A. Deactivation during carbon dioxide reforming of methane over Ni catalyst: Microkinetic analysis. Chem. Eng. Sci. 2001, 56, 1371-1379. [CrossRef]

92. Pechimuthu, N.A.; Pant, K.K.; Dhingra, S.C. Deactivation studies over $\mathrm{Ni}-\mathrm{K} / \mathrm{CeO} \mathrm{O}_{2}-\mathrm{Al}_{2} \mathrm{O}_{3}$ catalyst for dry reforming of methane. Ind. Eng. Chem. Res. 2007, 46, 1731-1736. [CrossRef]

93. Zhang, L.; Li, L.; Li, J.; Zhang, Y.; Hu, J. Carbon dioxide reforming of methane over nickel catalyst supported on $\mathrm{MgO}(111)$ nanosheets. Top. Catal. 2014, 57, 619-626. [CrossRef]

94. Koo, K.Y.; Roh, H.-S.; Seo, Y.T.; Seo, D.J.; Yoon, W.L.; Park, S.B. Coke study on MgO-promoted Ni/ $\mathrm{Al}_{2} \mathrm{O}_{3}$ catalyst in combined $\mathrm{H}_{2} \mathrm{O}$ and $\mathrm{CO}_{2}$ reforming of methane for gas to liquid (GTL) process. Appl. Catal. A 2008, 340, 183-190. [CrossRef]

95. Xu, L.; Song, H.; Chou, L. Carbon dioxide reforming of methane over ordered mesoporous $\mathrm{NiO}-\mathrm{MgO}-\mathrm{Al}_{2} \mathrm{O}_{3}$ composite oxides. Appl. Catal. B 2011, 108-109, 177-190. [CrossRef]

96. Wang, H.Y.; Ruckenstein, E. Carbon dioxide reforming of methane to synthesis gas over supported rhodium catalysts: The effect of support. Appl. Catal. A 2000, 204, 143-152. [CrossRef]

97. Ferreira-Aparicio, P.; Rodríguez-Ramos, I.; Anderson, J.A.; Guerrero-Ruiz, A. Mechanistic aspects of the dry reforming of methane over ruthenium catalysts. Appl. Catal. A 2000, 202, 183-196. [CrossRef]

98. Amenomiya, Y.; Morikawa, Y.; Pleizier, G. Infrared spectroscopy of C18O2 on alumina. J. Catal. 1977, 46, 431-433. [CrossRef] 
99. Daza, C.E.; Gallego, J.; Moreno, J.A.; Mondragón, F.; Moreno, S.; Molina, R. $\mathrm{CO}_{2}$ reforming of methane over $\mathrm{Ni} / \mathrm{Mg} / \mathrm{Al} / \mathrm{Ce}$ mixed oxides. Catal. Today 2008, 133-135, 357-366. [CrossRef]

100. King, J.S.; Wittstock, A.; Biener, J.; Kucheyev, S.O.; Wang, Y.M.; Baumann, T.F.; Giri, S.K.; Hamza, A.V.; Baeumer, M.; Bent, S.F. Ultralow loading Pt nanocatalysts prepared by atomic layer deposition on carbon aerogels. Nano Lett. 2008, 8, 2405-2409. [CrossRef] [PubMed]

101. Jeong, M.-G.; Kim, D.H.; Lee, S.-K.; Lee, J.H.; Han, S.W.; Park, E.J.; Cychosz, K.A.; Thommes, M.; Hwang, Y.K.; Chang, J.-S.; et al. Decoration of the internal structure of mesoporous chromium terephthalate MIL-101 with $\mathrm{NiO}$ using atomic layer deposition. Microporous Mesoporous Mater. 2016, 221, 101-107. [CrossRef]

102. Ferguson, J.D.; Weimer, A.W.; George, S.M. Atomic layer deposition of ultrathin and conformal $\mathrm{Al}_{2} \mathrm{O}_{3}$ films on BN particles. Thin Solid Films 2000, 371, 95-104. [CrossRef]

103. Kaiser, N. Review of the fundamentals of thin-film growth. Appl. Opt. Appl. Opt. 2002, 41, 3053-3060. [CrossRef] [PubMed]

104. Aaltonen, T.; Ritala, M.; Sajavaara, T.; Keinonen, J.; Leskelä, M. Atomic layer deposition of platinum thin films. Chem. Mater. 2003, 15, 1924-1928. [CrossRef]

105. Jeong, M.-G.; Kim, I.H.; Han, S.W.; Kim, D.H.; Kim, Y.D. Room temperature CO oxidation catalyzed by NiO particles on mesoporous $\mathrm{SiO}_{2}$ prepared via atomic layer deposition: Influence of pre-annealing temperature on catalytic activity. J. Mol. Catal. A Chem. 2016, 414, 87-93. [CrossRef]

106. Kaydouh, M.N.; El Hassan, N.; Davidson, A.; Casale, S.; El Zakhem, H.; Massiani, P. Highly active and stable Ni/SBA-15 catalysts prepared by a "two solvents" method for dry reforming of methane. Microporous Mesoporous Mater. 2016, 220, 99-109. [CrossRef]

107. Kang, D.; Lim, H.S.; Lee, J.W. Enhanced catalytic activity of methane dry reforming by the confinement of Ni nanoparticles into mesoporous silica. Int. J. Hydrogen Energy 2017, 42, 11270-11282. [CrossRef]

108. Shang, Z.; Li, S.; Li, L.; Liu, G.; Liang, X. Highly active and stable alumina supported nickel nanoparticle catalysts for dry reforming of methane. Appl. Catal. B 2017, 201, 302-309. [CrossRef]

109. Han, S.W.; Kim, I.H.; Kim, D.H.; Park, K.J.; Park, E.J.; Jeong, M.-G.; Kim, Y.D. Temperature regulated-chemical vapor deposition for incorporating $\mathrm{NiO}$ nanoparticles into mesoporous media. Appl. Surf. Sci. 2016, 385, 597-604. [CrossRef]

110. Kim, I.H.; Seo, H.O.; Park, E.J.; Han, S.W.; Kim, Y.D. Low temperature CO oxidation over Iron oxide nanoparticles decorating internal structures of a mesoporous alumina. Sci. Rep. 2017, 7, 40497. [CrossRef] [PubMed]

111. Kim, I.H.; Park, E.J.; Park, C.H.; Han, S.W.; Seo, H.O.; Kim, Y.D. Activity of catalysts consisting of $\mathrm{Fe}_{2} \mathrm{O}_{3}$ nanoparticles decorating entire internal structure of mesoporous $\mathrm{Al}_{2} \mathrm{O}_{3}$ bead for toluene total oxidation. Catal. Today 2017, 295, 56-64. [CrossRef]

112. Kim, I.H.; Park, C.H.; Woo, T.G.; Jeong, J.H.; Jeon, C.S.; Kim, Y.D. Comparative Studies of Mesoporous $\mathrm{Fe}_{2} \mathrm{O}_{3} / \mathrm{Al}_{2} \mathrm{O}_{3}$ and $\mathrm{Fe}_{2} \mathrm{O}_{3} / \mathrm{SiO}_{2}$ fabricated by temperature-regulated chemical vapour deposition as catalysts for acetaldehyde oxidation. Catal. Lett. 2018, 148, 454-464. [CrossRef]

113. Seo, M.; Kim, S.Y.; Kim, Y.D.; Park, E.D.; Uhm, S. Highly stable barium zirconate supported nickel oxide catalyst for dry reforming of methane: From powders toward shaped catalysts. Int. J. Hydrogen Energy 2018, 43, 11355-11362. [CrossRef]

(C) 2019 by the authors. Licensee MDPI, Basel, Switzerland. This article is an open access article distributed under the terms and conditions of the Creative Commons Attribution (CC BY) license (http://creativecommons.org/licenses/by/4.0/). 